\title{
Factors Affecting the Environmentally Induced, Chronic Kidney Disease of Unknown Aetiology in Dry Zonal Regions in Tropical Countries-Novel Findings
}

\author{
Sunil J. Wimalawansa $1, *(1)$ and Chandra B. Dissanayake ${ }^{2}$ \\ 1 Cardio Metabolic \& Endocrine Institute, North Brunswick, NJ 08902, USA \\ 2 Department of Geology, University of Peradeniya, National Institute of Fundamental Studies, Kandy 20000, \\ Sri Lanka; cbdissa@gmail.com \\ * Correspondence: suniljw@hotmail.com
}

Received: 20 November 2019; Accepted: 11 December 2019; Published: 18 December 2019

\begin{abstract}
A new form of chronic tubulointerstitial kidney disease (CKD) not related to diabetes or hypertension appeared during the past four decades in several peri-equatorial and predominantly agricultural countries. Commonalities include underground stagnation of drinking water with prolonged contact with rocks, harsh climatic conditions with protracted dry seasons, and rampant poverty and malnutrition. In general, the cause is unknown, and the disease is therefore named CKD of unknown aetiology (CKDu). Since it is likely caused by a combination of factors, a better term would be CKD of multifactorial origin (CKDmfo). Middle-aged malnourished men with more than 10 years of exposure to environmental hazards are the most vulnerable. Over 30 factors have been proposed as causative, including agrochemicals and heavy metals, but none has been properly tested nor proven as causative, and unlikely to be the cause of CKDmfo/CKDu. Conditions such as, having favourable climatic patterns, adequate hydration, and less poverty and malnutrition seem to prevent the disease. With the right in vivo conditions, chemical species such as calcium, phosphate, oxalate, and fluoride form intra-renal nanomineral particles initiating the CKDmfo. This article examines the key potential chemical components causing CKDmfo together with the risk factors and vulnerabilities predisposing individuals to this disease. Research findings suggest that in addition to drinking water from stagnant sources that contain high ionic components, more than 10 years of exposure to environmental nephrotoxins and micronutrient malnutrition are needed to contract this fatal disease.
\end{abstract}

Keywords: chronic renal failure; $\mathrm{CKD}$; $\mathrm{CKDu}$; environment; fluoride; geochemistry; hardwater; malnutrition; nanocrystals and nanotubes; nephropathy; tropical countries; tubulointerstitial

\section{Introduction}

The prevalence of common chronic diseases is increasing worldwide, including type 2 diabetes (T2D), metabolic syndrome, obesity, and chronic kidney disease (CKD) [1]. Collectively, these diseases significantly increase morbidities and premature deaths [2]. An unusual form of CKD, occurring in the absence of diabetes and hypertension, has emerged over the past four decades in several economically poor, predominantly agricultural, equatorial (tropical) countries, killing more than 30,000 people each year [3].

Data points toward a combination of multiple factors and conditions causing this fatal disease, and a more accurate term would be "CKD of multifactorial origin" (CKDmfo). Because the cause remains unknown, the disease is also called "CKD of unknown origin" (CKDu) [4-6]. In disease-affected 
regions, many families have abandoned home gardening and traditional agricultural methods, altered their traditional balanced diet to consist predominantly of carbohydrates, and adopted new eating and drinking habits. Human behaviour and types of food consumed are comparable in affected and non-affected regions; differences include the quality of water, degree of hydration and amount of water consumed, poverty, and malnutrition.

\subsection{Demographics Associated with CKDmfo}

This review focuses on CKDmfo in Sri Lanka, based on the data collected over two decades. Sri Lanka is a tropical country, located 740 kilometres north of the equator. Because of the similarities within most of the CKDmfo/CKDu-affected countries, the data and concepts discussed are applicable to all countries affected by this disease. In Sri Lanka, three provinces [North Central (NCP), Uva, and Wayamba] are predominantly affected $[7,8]$.

In Sri Lanka, three million people are at risk of CKDmfo in an approximate area of $30,000 \mathrm{~km}^{2}$. Over 250,000 people are affected, and approximately 5000 die each year, including at least one disease-related suicide per day [4,6,9-11]. The group affected most is middle-aged male farmers (primarily daily paid labourers) [6,11-13]. CKDmfo-affected villages are distributed geographically in a heterogeneously and discontinuous manner, intermingling with non-affected villages [14], which suggests a geochemical influence.

Affected and non-affected villages have similar lifestyles, cultural habits, and socioeconomic conditions; the key differences are significantly more malnutrition and inferior quality of drinking water in the affected regions. More than one-third of those affected do not receive western medical treatment (opting out of attending governmental clinics and hospitals), and approximately half die at home. This is in part because of costs, travel difficulties and inconvenience, and attempts to minimize the societal stigma associated with the disease [6]. Thus, annual morbidity and mortality statistics of the department of health (exclusively derived from hospital data) capture fewer than half and are significantly inaccurate.

\subsection{Geographical Distribution of CKDmfo}

All affected regions have experienced increased daytime average temperatures and prolonged droughts that markedly affect water quality and vegetation, presumably due to climate change. Most people with the disease consume water from shallow wells that are located below irrigation canals. Similarly, relationships between CKDmfo and the mentioned geographic variables, such as the use of agrochemicals, heavy metals (HMs), and fluoride, are not sufficiently understood. Data suggest that the disease predominantly affects those who consume surface water from shallow wells (and tube wells) located on flat land with higher water-rock interaction. [15]. By contrast, drinking water obtained from reservoirs, streams, springs, and canals does not cause the disease $[4,6,14]$, which supports a geogenic aetiology of the disease.

The geographic distribution of the illness is not uniform (nor is the distribution of water content of fluoride across the region or other postulated elements), and the manifestation of the disease is heterogeneous. For example, it is common to observe clusters of disease-affected households in non-contiguous areas separated by villages that have little prevalence of CKDmfo $[4,6,16]$. Within the NCP region, villagers who consume water from natural springs have the lowest prevalence (less than $2 \%$ among adults) of the disease $[6,17]$ compared with prevalence of more than $20 \%$ in neighbouring villages. This further strengthens the hypothesis that, in contrast to food, water is the source of the disease, with a strong emphasis on water chemistry.

\subsection{Diagnosis of CKDmfo}

The common forms of CKD secondary to chronic hypertension and T2D predominantly affect glomeruli $[18,19]$, so proteinuria is an early sign of the disease. The histopathologic manifestation and urinary biochemical marker excretion of the above-mentioned, common form of CKD is different from 
that of CKDmfo [20-23]. CKDmfo is a tubular disease and thus, protein urea is a late manifestation. Consequently, measurement of urinary (micro) albumin:creatinine ratio (ACR or MCR) is a non-specific and an insensitive marker that should not be used for diagnosis or screening. Tubular-specific biomarkers are excreted from the early stage of CKDmfo because it is a predominantly renal tubular disease $[4,6,24,25]$. Thus, such biomarkers can be used as a sensitive and specific marker for screening and early diagnosis.

\subsection{Urinary Biomarkers for CKDmfo}

Unlike the common form of CKD and glomerular nephritic diseases, such as nephrotic syndrome, CKDmfo affects renal tubular cells with relative sparing of glomeruli until CKD stage $3[10,26]$. Because albumin or proteinuria is not an early sign of this disease, the use of the ACR or MCR as a biomarker, having less than $50 \%$ sensitivity and specificity in identifying CKDmfo is inappropriate [16,24]. Despite this, proteinuria continues to be used by the Department of Health in Sri Lanka and all other CKDmfo-affected countries. This testing method identifies fewer than half of those with early stages of CKDmfo, causing harm to those whose disease remains unidentified $[10,24,27]$.

Damage to renal tubules leads to urinary excretion of tubular-specific biomarkers. However, low molecular weight proteins and large peptides also leak through the basement membrane of glomeruli under physiological conditions [28]. However, most of these get reabsorbed via the renal tubules resulting in only little being excreted in urine. However, in tubular diseases, some of the glomerular-derived low molecular weight proteins begin to appear in urine because of the failure of reabsorption [29]. Thus, in those with early renal failure due to renal tubular disease, one could measure the proteins that leak from the glomeruli that are not reabsorbed and also those protein/biomarkers that secrete from the tubular cells $[4,6,24,25]$. Thus, low molecular weight urinary biomarkers (but not albumin) can be used as a sensitive and specific marker for screening and early diagnosis [29].

L-FABP is a $14 \mathrm{kDa}$ protein present in the cytoplasm of human renal proximal tubules. L-FABP is also a transport protein that carries long-chain fatty acids to the mitochondria and peroxisomes, also acting as an endogenous antioxidant $[30,31]$. Urinary L-FABP has been reported as a specific marker of tubulointerstitial damage and correlates with the progression of CKD. Moreover, it is more sensitive than urinary protein in predicting the progression of CKD [30]. Urinary L-FABP on its own or in combination with other renal tubular markers, such as neutrophil gelatinase-associated lipocalin (NGAL) or kidney injury molecule-1 (KIM-1), can be effectively used to diagnoses tubular injuries [32,33].

\subsection{Prognosis of CKDmfo}

Many who are screened using MCR have CKDmfo diagnosed beyond stage 3A. Because such late diagnosis of CKDmfo precludes rescuing their kidneys, most patients progress to full-blown end-stage renal disease that requires dialysis resulting in premature death. To save lives, it is essential to identify the disease earlier than stage $3 \mathrm{~A}$ using one of several sensitive and specific, tubular-specific urinary (or serum) biomarkers. This would allow those with early-stage disease to receive effective measures to reverse disease course and prevent deaths $[4,6,34]$.

Because the use of nonspecific and insensitive screening methods leads to under-diagnosis, there is a gross underestimation of the number of persons with CKDmfo [11-13]. Considering the lesser sensitivity and specificity of ACR or MCR, one could estimate that approximately $40 \%$ of those with the disease are identified through screening, making the government $\mathrm{CKDu}$-related statistics unreliable. In addition, one-third of persons with CKDmfo do not attend clinics in government hospitals [4,9-11].

\subsection{Summary of Proposed Causes of CKDmfo}

Proposed causes of CKDmfo include agrochemicals; fungi, algae, and microbial toxins; viruses and spirochetes; heavy metals (HMs); high-fructose diets; heat stress and chronic dehydration (due to excessive sweating, reduced water intake because of unpalatable hard water, and daily ingestion of 
illicitly brewed alcohol); abuse of non-steroidal anti-inflammatory agents [35]. Exposure to high doses of some of the above have been shown to cause acute renal failure with associated renal damage that can lead to chronic renal failure [36,37]. Here we proposed that CKDmfo/CKDu is caused by a combination of naturally present elements in drinking water-hard water, $\mathrm{Ca}^{2+}, \mathrm{PO}_{4}{ }^{3-}$, fluoride, etc., when the susceptibility conditions are prevalent.

Of the postulated agents, only fluoride is present in drinking water in the region in concentrations higher than the maximum allowable limits (MAL) and that can cause renal tubular damage [6,38]. Only other chemical constituent present higher concentration is surface water is phosphates [39]. However, the amount of phosphate present is water, such as in reservoirs are insufficient to cause renal damage or noticeable harm to humans and animals [12]. Toxins such as snake venom and high doses of HMs [e.g., cadmium $(\mathrm{Cd})$, lead $(\mathrm{Pb})$, or metalloid arsenic] also cause direct renal damage [37,40], whereas fluoride and aristolochic acid cause tubular cell harm via destruction of intracellular functions and oxidative damage [41], via caspase-mediated DNA damage, inflammation, cell apoptosis, and subsequent renal tissue fibrosis [42,43].

Additional anthropogenic contaminants of water include emissions from coal-fired power plants and other air- and water-polluting industrial sources, including fluoride and HMs. However, none of the investigations have reported meaningful concentrations of any HMs or $\mathrm{F}^{-}$in drinking water or locally grown food in Sri Lanka [44]. Much fluoride in water comes from natural, geological sources, such as the mica, hornblende, fluorite, and fluorochloro-hydroxyapatite deposits abundant across the NCP. Such underground deposits occur in the Eppawala region in NCP, where there is a large phosphate deposit that extends about $120 \mathrm{~km}$ to the south. In fact, since 2013, new cases of CKDmfo have been reported in the southern region within and around the "fluoride belt" of Sri Lanka $[6,10,27]$. However, whether this is related to groundwater fluoride remains unknown.

\subsection{Physiology of Renal Filtration Unit}

The filtration of blood starts at millions of glomeruli in the nephron. It is a biological sieve that separate serum protein and blood cells allowing the filtration fluid to pass through glomerular basemen membranes into Bowman's capsules to become urine. The pressure difference between the afferent (incoming) and efferent arteriole (blood goes back to the systemic circulation) within the glomerulus, enable the needed filtration pressure to separate urine component.

This filtered fluid containing smaller protein, peptides and large number of dissolved particles and ions, passes through different sections of the nephron segments. From the glomeruli, urine enters the proximal convoluted tubule, which is the most metabolically active. Most of the nephrotoxins entering to nephrons via renal arterioles and through tubular fluids, will enter proximal convoluted tubules. Most of these toxins get neutralized by multiple mechanisms and excreted, but some will initiate intra-cellular inflammation and tubular cell damage.

Tubular fluids then pass into the medulla-descending and ascending limbs-the loops of Henle in the interstitium, where the countercurrent exchange of solutes occurs [19]. Nephron tubules crisscross the outer cortex to inner medulla and back several times. During this transit, active transportations and resorption of ions occurs, continue to concentrate intra-tubular fluid-urine. This complex process with counter-current multipliers, occur different sections of the tubules, preferentially absorb different compounds, continuing to concentrate urine. Toward the end, distal convoluted tubules join with the collecting duct draining urine into the renal pelvis, then to the bladder via two ureters. As described in the next section, because of the proximal location and highly metabolically active, including number of ion transportation, these cells are the first to get affected in nephrons. 


\subsection{CKDmfo: General Pathology}

Renal tubular cell failure manifests after exposure to nephrotoxins. It leads to tubular cell damage and obstruction associated with interstitial inflammation, reno-microvascular contraction, and chronic intravascular volume depletion, in part caused by chronic dehydration and the effects of raised renin-angiotensin hormonal system [27,45], which exacerbates tubular oxidative stress [46]. CKDmfo is a fatal chronic tubulointerstitial disease in which renal tubules get blocked and inflamed in early stages $[6,47]$. With the gradual local spread of chronic inflammation and fibrosis, the entire kidney is affected $[26,48]$.

Renal biopsies from people affected with CKDmfo demonstrate chronic interstitial nephritis associated with tubular atrophy (shrunken kidneys). In affected countries, such as Sri Lanka, India, and Mesoamerican countries (e.g., El Salvador and Nicaragua), CKDmfo is a major public health and economic problem that causes significant morbidity and mortality, and economic difficulties and food insecurity. Patients with CKDmfo do not have excess prevalence of metabolic/mineral bone disease (CKD-MBD) [49].

\subsection{Toxic Tubular Nephropathy}

Kidneys are essential for maintaining normal calcium, phosphorus, and magnesium homeostasis, which are disrupted in the presence of renal failure. Most nongenetic renal tubulointerstitial diseases generally are attributed to exposure to chemical nephrotoxins $[4,6,10,16]$, which can be acute (e.g., snake venom, drugs, toxins, infections, immunological reactions) or chronic, as in the case of CKDmfo. Chronic tubulointerstitial renal diseases can be caused by nephrotoxic substances, such as HMs, fluoride, or reflux nephropathy [47,50-54].

Taken together the higher physical activity-associated formation of lactic acid and recurrent dehydration mentioned, further reduce GFR and create a favourable internal environment for the build-up of metabolic products such as urate in the kidney and facilitate renal fibrosis $[6,45,55]$. In addition to hydroxyapatite formation, dehydration and acidic conditions facilitate the formation of microcrystals, especially urate within the kidney [56,57].

We propose that CKDmfo is caused by the formation of nanotubes and nanocrystals in renal tubules. These mineral particles consist primarily of hydroxyapatite and fluoroapatite compounds but also may contain calcium oxalate ( $\mathrm{CaOx})$ [58] within renal tubular cells and in the tubular lumen [59]. These mineral nanoparticles can cause tubular damage and initiate local inflammation, leading to interstitial fibrosis [60]. Similar findings have been reported with myeloma-light chain-associated proximal tubulopathy with crystal formation [61,62]; the appearance of which is similar to that seen with CKDmfo. Figure 1 illustrates the conceptual drawing of a parts of a nephron, demonstrating the process of nanomineral formation in renal tubules.

The figure demonstrates a schematic drawing of a human renal filtration unit (a papilla), how intratubular nanomineral and nanotubes form, with progression of urine concentration through the tubules [60]. As discussed in the Section 1.9, nanominerals are formed in both renal tubules and within tubular cell cytoplasm [59]. With chronic persisting supersaturation of tubular fluid, $\mathrm{CaPO}_{4}$ nanoparticles with continue to grow [63]; however, the rate of growth is very slow, thus the disease takes over a decade to manifest. In addition to growth, these nanoparticles agglomerate, and some incorporates $\mathrm{F}^{-}$forming stable fluoroapatite. Growth and aggregation of nanotubes cause nano-ruptures of tubular wall exacerbating the inflammation and fibrosis (lower part of the figure-modified from Wiener S.V., et al, 2018; [64]). 


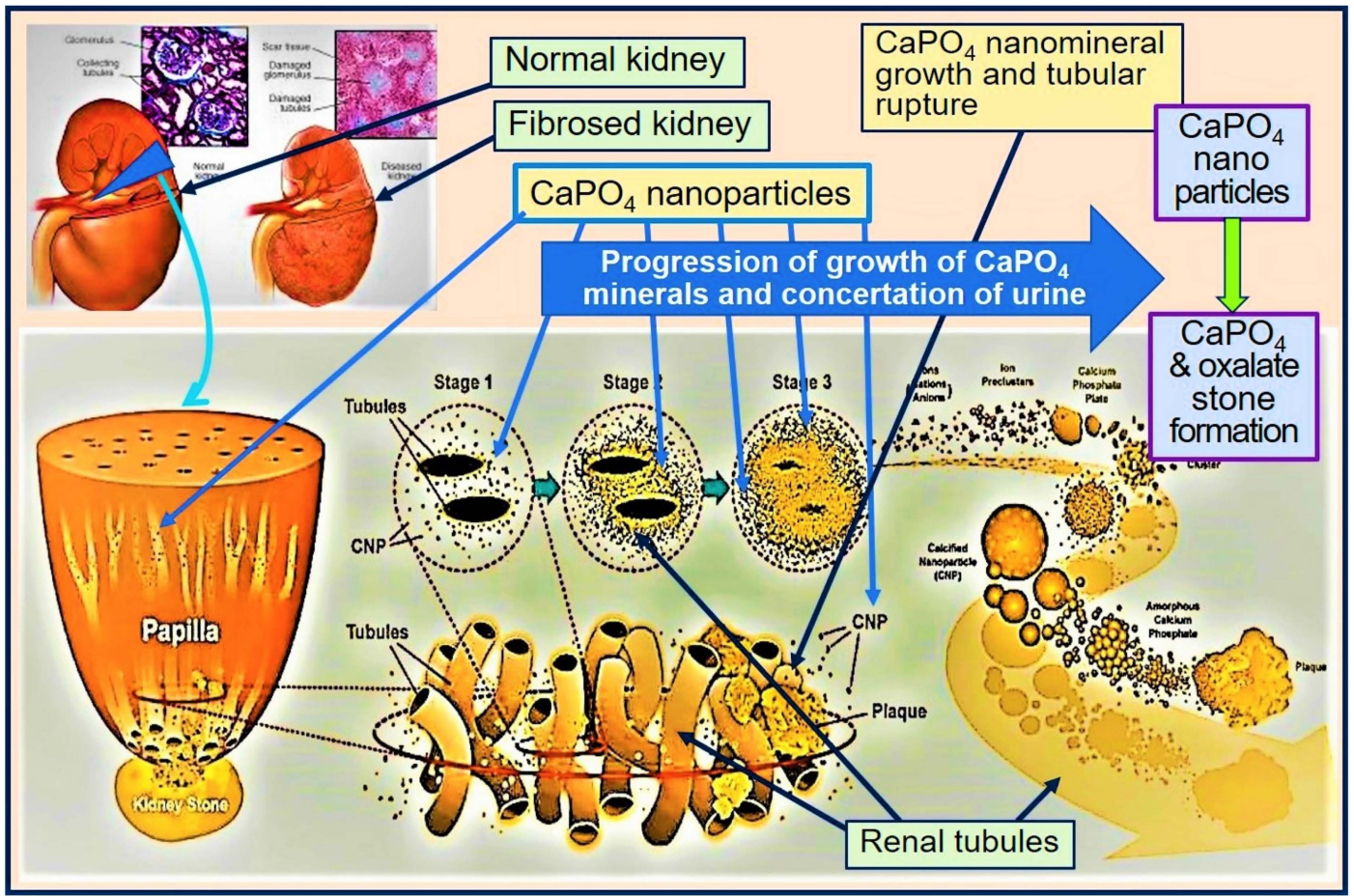

Figure 1. Schematic illustration of the process of nanomineral formation in renal tubules.

\subsection{Factors that Lead to Prolongation of the Disease}

Escalating poverty and assonated malnutrition, and prolonged dry spells enhances the incidence of CKDmfo in the affected regions. The widespread use of ineffective domestic water filters and the provision of inadequately purified drinking water from the National Water Board provide a false sense of security to consumers about water quality. The latter occurs primarily because of the lack understanding by the lawmakers and implementers—government employees—of the gio-bio pathways and their adverse effects on humans.

Consequently, villagers are encouraged to consume higher volumes of locally available water containing mentioned pollutants, resulting further increase of ingestion of nephrotoxic agents. The latter includes, $\mathrm{Ca}^{2+}, \mathrm{PO}_{4}{ }^{3-}$, and fluoride, creating internal milieu for nanomineral precipitation and renal damage $[10,16]$. This is particularly worse during the latter part of the dry season; when the stagnant well-water becomes highly concentrated with dissolve substances (TDS) and toxins. Combination of these facilitate perpetuating of favourable conditions for nanomineral precipitation in vivo, that spreads over more than six months, each year.

Most people in the region feel better during the three to four months of rainy season. Nevertheless, the stepwise cumulative harm to kidneys continue for several years prior to manifesting clinical signs and symptoms of CKDmfo/CKDu. Thus, the increasing incidence and the prevalence of CKDmfo in specific, geographically demarcated regions. The combination of escalating environmental pollution, poverty-related malnutrition, over-exploitation of groundwater through agro-wells, and cycles of extended severe drought followed by flash flooding, aggravate general ill health, particularly CKDmfo.

\section{Extenuating Factors Affecting CKDmfo}

The kidneys are vital for metabolic waste management, glucose handling, electrolyte homeostasis, production of certain hormones, and blood pressure regulation. They receive more than $20 \%$ of their blood supply from the heart and are metabolically highly active. Kidneys also neutralize and detoxify toxins and excrete unwanted substances from the body. Thus, the kidneys can be affected by multiple means. 
Metallothioneins I/II (MT) are expressed in mammalian cells and are inducible in the response to oxidative stress conditions, and also have protective and antiapoptotic effects in renal proximal tubular cells [65]. An endogenous antioxidant MT can be induced by both zinc (Zn) and renal ischemia. By inducing MT, cations such as $\mathrm{Zn}$ and selenium (Se) protect critical tissues such as renal tubules and reduction of kidney function [66]. Binding of MT to HMs, such as cadmium and arsenic making them non-toxic and thus protects kidneys [67]. Nevertheless, there is no scientific data that drinking water in Sri Lanka or in any other disease affected countries are contaminated with heavy metals [44].

\subsection{CKDmfo and Chronic Exposure to Nephrotoxins}

Based on two decades of community-based data, one of the authors (SJW) estimates that more than 10 years of persistent environmental toxic exposure is necessary before clinical manifestation of CKDmfo [10,13]. On average, affected adults have been exposed to environmental nephrotoxins (including contaminated drinking water) for between 10 and 18 years before they develop signs and symptoms of CKDmfo. Because of the prolonged prodromal period, children are rarely affected. However, exposure to higher doses and inherent vulnerability, such as micronutrient deficiencies, can reduce this incubation period.

Data strongly suggest that a combination of factors (hence the terminology, CKDmfo), including multiple geogenic and nephrotoxic factors, changes in lifestyles, and environmental conditions, working additively, increase personal vulnerabilities to this disease. The latter includes escalating poverty and associated antioxidant and micronutrient deficiencies, the consumption of a predominantly carbohydrate diet with a high content of fructose, frequent ingestion of fluoride and alcohol, and chronic recurrent dehydration.

\subsection{Sources of Water Contamination with Nephrotoxins}

Consumption of contaminated water containing nephrotoxins, such as excess fluoride, cadmium, lead, arsenic, or uranium, etc., is known cause tubule-nephropathy. However, none of the investigations have reported meaningful concentrations of the HMs in drinking water in Sri Lanka [44]. Groundwater contamination with geogenic components is common in CKDmfo-affected regions. This is primarily attributable to weathering of underground rocks, seismic effects, and other geogenic effects. However, anthropogenic water contamination is increasingly common. Such contamination is caused by the careless use of agrochemicals, industrial effluents and discharges, flooding, emissions from coal-powered plants, and so forth.

\subsection{Mechanisms Initiating Tubular Inflammation and Fibrosis Leading to CKDmfo}

Analyses of water samples in multiple studies indicated the lack of proposed nephrotoxins in drinking water in both CKDmfo-affected and non-affected regions [8,68-71]. Analysed components include $\mathrm{HMs}(\mathrm{Cd}, \mathrm{Pb}, \mathrm{As}$, and $\mathrm{Cr}$ ), agrochemicals (fertilizers and pesticides), and toxins such as ochratoxin, algae-related toxins, organochlorines, and organophosphates. An occasional water sample had detectable concentrations of pesticides but levels were well below the WHO-recommended upper limits $[5,72,73]$.

Kidneys are essential for maintaining normal $\mathrm{Ca}^{2+}, \mathrm{PO}_{4}{ }^{3-}$, and $\mathrm{Mg}^{2+}$ homeostasis, which is disrupted in the presence of renal failure. However, the concentrations of $\mathrm{PO}_{4}{ }^{3-}, \mathrm{F}^{-}$, and $\mathrm{Ca}^{2+}$ are somewhat elevated in many drinking water samples in the NCP, and levels are several times greater during the dry season. The concentrations of these elements also markedly vary depending on how and when water samples were collected. Water samples from the same well can have a twofold difference depending on whether the sample was collected early in the morning or evening or from the surface or the bottom of the well.

We have observed more than a 20-fold increase in contaminants during the end of the dry season compared with those taken during the rainy season, which highlights the importance of the timing and mode of water collection. One should not rely on reported water quality data from random water 
samples or even systematic sampling collected only during the wet season. Such data are unreliable and should not be correlated with disease status or extrapolated for the region.

On average, the dry season in the NCP lasts up to 9 months. Water levels in stagnant shallow wells that are not connected to the underground water channel become highly concentrated with $\mathrm{Ca}^{2+}$, $\mathrm{PO}_{4}{ }^{3-}, \mathrm{F}^{-}$, and other elements because of water usage and evaporation (for example of such wells, see Figure 2). Despite this, most people continue to drink such water because no other water sources are conveniently available.

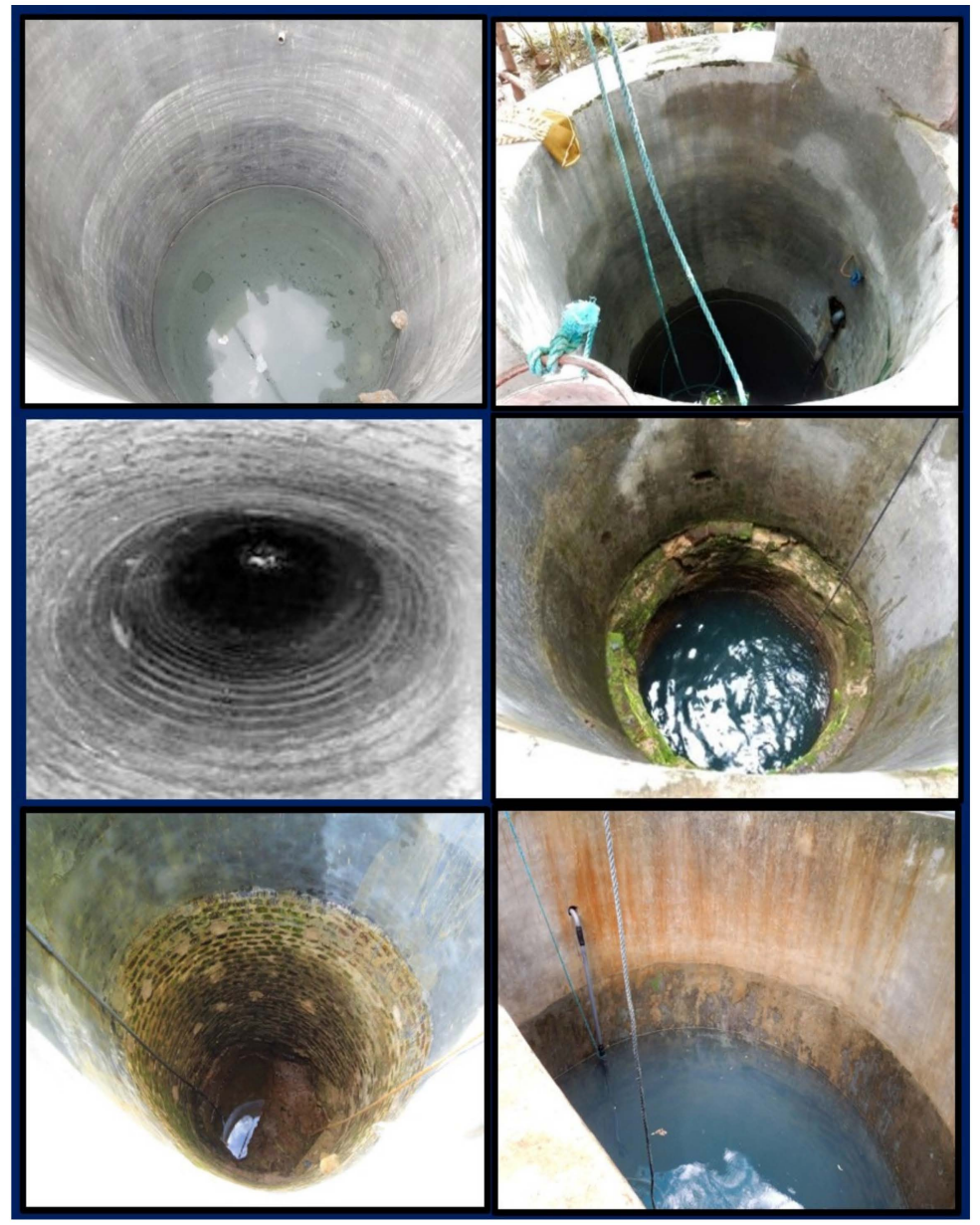

Figure 2. Typical wells in the dry zone in NCP region, toward the end of the dry season. Different wells from the CKDmfo affected villages have varied water levels during the middle of a day season.

During the dry season, the temperature rises while farmers continue to work outdoors to cultivate and prepare fields for the rainy season. To compensate for excessive sweating, farmers consume the concentrated hard water despite its unpalatable taste. Most farmers also regularly consume alcohol in the evening, often on a daily basis, making dehydration worse. Consequently, urine and the renal tubular fluid of these people become highly concentrated and saturated with the mentioned ions. This creates a favourable condition for precipitation of hydroxyapatite nanotubes and nanominerals within renal tubular tissues.

We hypothesize that, nanocrystals and nanotubes of the mineral hydroxyl/fluorapatite are formed in renal tubular cells and in lumens and continue to grow over time. The incorporation of $\mathrm{F}^{-}$into these nanoparticles makes fluoroapatite more stable and allows their growth with less degradation. Nanomineral deposits in renal tubular cells and interstitial tissues are inflammatogenic, attracting (A) macrophages that liberate cytokines, causing low-grade local inflammation, and (B) fibroblasts causing fibrosis. In addition, the growth of nanomineral particles within renal tubules causes tubular blockage. 
These initiate and maintain inflammation and fibrosis, resulting in tubular cell damage, apoptosis, and loss of functions.

\subsection{Relationship of Drinking Water and CKDmfo}

Most people with CKDmfo consume water from household, stagnant shallow wells that are not connected to the underground water table or deep tube wells [6,14]. However, the prevalence of CKDmfo is low among those who consume surface water from dynamic water sources, such as reservoirs, streams, irrigating canals, and natural springs [68,71]. Meanwhile, there is no evidence that well water in Sri Lanka and other CKDmfo-affected countries is contaminated with fertilizers, pesticides, or HMs causing CKDmfo [14,68,74-76].

Because of the poor connectivity of shallow wells to the main groundwater table [71], it is hard to envisage the anthropogenic source of nephrotoxic contaminants, other than natural geogenic sources. Nevertheless, what is important is not the total amount of a substance in water but its species (as with arsenic and chromium), bioavailable components, and possible interactions. For example, although the total fluoride content in water (and food) can exceed $2.0 \mathrm{mg} / \mathrm{day}$, the bioavailable portion could be much less [77,78].

\subsection{Contribution of Agrochemicals and Pollution to CKDmfo}

No scientific data support that water draining from the hilly regions of the country, during any part of the weather cycle, to the dry zone and other parts of the country, via major rivers, has any effect on causing CKDmfo $[8,79,80]$. In addition, no scientific studies have reported higher concentrations of any agrochemicals (e.g., more than the MAL), except phosphate, in any of the river waters $[8,81,82]$. Moreover, because the studies reported are haphazard, non-systematic, and poorly designed, data cannot be pooled for meta-analysis.

Broader sets of data from Sri Lanka suggest that there is no connection between agriculture and agrochemicals causing this deadly disease. However, prolonged contact of underground water channels with certain rock formations that provide mineral-rich water and the effects from the prolonged dry season make water in shallow wells highly concentrated with minerals in the affected regions, which at least in part contributes to the genesis of CKDmfo.

Published data do not support any of the postulated nephrotoxic components as the single cause of CKDmfo. Little attention been given to the effects of interactions (i.e., additive or synergistic) among multiple agents. Similarly, no credible scientific data exist to support that fertilizers or pesticides, including glyphosate, organochlorine, or organophosphate, cause CKDmfo/CKDu in Sri Lanka or elsewhere $[6,7,10,83]$.

\subsection{Fluoride in Drinking Water and CKDmfo}

Excess fluoride has been present in water in the NCP region for centuries and is a natural geochemical phenomenon. However, because of over-exploitation of groundwater in the NCP region through agro-wells, fluoride-containing water rises to the surface, gradually increasing water $\mathrm{F}^{-}$ content. The increased $\mathrm{F}^{-}$content may have been facilitated by increased evaporation associated with the climatic change and underground seismic activities. Moreover, thousands of deep tube wells (and agro-wells) have been constructed in the CKDmfo-affected regions during the last four decades, increasing the $\mathrm{F}^{-}$content in water and the volume of contaminated water brought to the surface.

Residents of the wet region of the country are not affected with CKDmfo. In fact, all districts that are affected by CKDmfo are located in the dry zonal region, and many have well water with higher fluoride contents [10]. Figure 3 provides graphical information regarding the potential relationships between major rivers and patterns of drainage (A, B), climatic zones (C), geographic distribution of groundwater hardness (D), distribution of water fluoride content in comparison (E), and the distribution and pattern of spread of CKDmfo in Sri Lanka (F) $[4,6,70,82,84-87]$. 


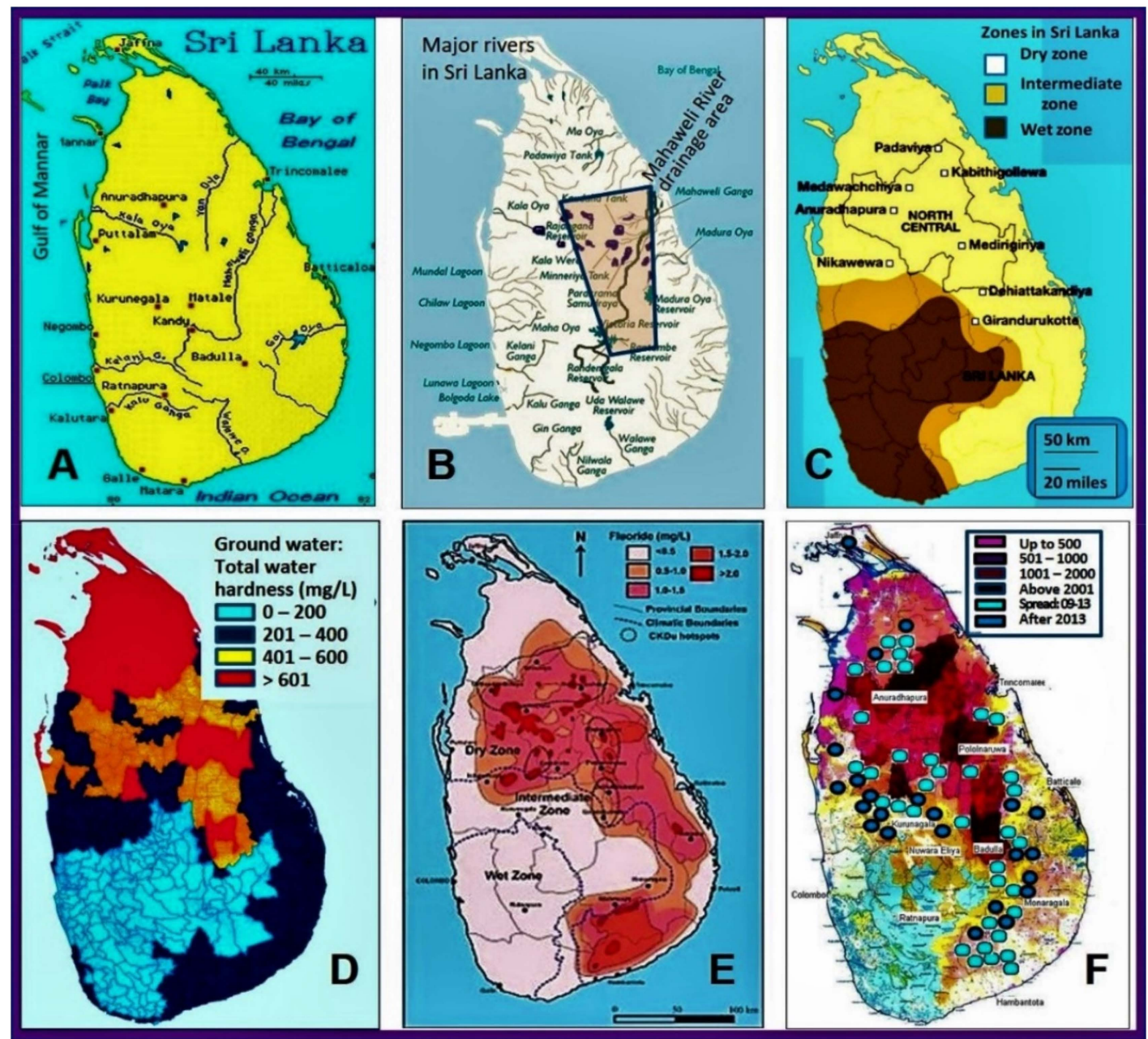

Figure 3. Illustrates drainage and rain patterns, hard water and fluoride distribution, and the density of distribution of persons with CKDmfo in Sri Lanka: (A) major rivers in Sri Lanka and their drainage patterns; (B) the drainage area (depicted in the pink box) of the Mahaweli River, the nation's longest river; (C) three climatic zones in Sri Lanka; (D) geographic distribution of groundwater hardness; (E) geographic distribution of fluoride; and (F) the distribution and spread of persons with CKDmfo from the 1990s onward. These figures were modified from previously published data sets and figures and from the Internet $[4,6,70,82,84-87]$.

\subsection{Excess Fluoride Intake from Water}

Fluoride gets into human bodies mostly via water and food, including tea, but a small quantity may enter the body through inhalation and fluoridated toothpaste. In water, fluoride ions form strong complexes with cations, such as aluminium. The bioavailable $\mathrm{F}^{-}$concentration in water depends on the $\mathrm{pH}$ and presence of cations, such as aluminium, calcium, and magnesium, which reduce the bioavailability of fluoride. However, greater residence time or increase of water $\mathrm{pH}$ enhance the bioavailable $\mathrm{F}^{-}$levels.

Groundwater with high $\mathrm{F}^{-}$concentrations generally is associated with fluorine-rich minerals contained in crystalline rock (e.g., granite and acidic volcanic rock with abundant high-fluoride minerals such as biotite, amphibole, apatite, and fluorite) but is also seen in water with protracted contact with aquifers, ion exchange in sedimentary aquifers, arid areas with shallow aquifers experiencing strong cyclic evaporation, and in geothermal water $[4,6]$. Thus, in CKDmfo-affected areas, sustainable water management should encompass the management of geogenic contaminants in water. 


\subsection{Dental and Skeletal Fluorosis and CKDmfo}

Dental fluorosis requires consumption of fluoride-rich water (e.g., more than $1.2 \mathrm{mg} / \mathrm{L}$ ) for a prolonged period. This is not uncommon in the CKD-affected dry zonal regions. However, except for a handful of patients, there is no evidence of widespread existence of skeletal fluorosis in any of the CKDmfo-affected regions in Sri Lanka or other affected countries. In general, the manifestation of skeletal fluorosis requires the ingestion of higher quantities of fluoride (e.g., more than $7 \mathrm{mg} / \mathrm{L}$ ) for many years [88,89]. In the provincial hospitals in the affected regions in Sri Lanka, dozens of plain radiographs coming from a few families in the region, have been reported as skeletal fluorosis.

In most of the cases mentioned, radio opaque $x$-rays actually indicate osteosclerosis and not skeletal fluorosis, a hereditary disease also known as Albers-Schönberg disease and marble bone disease [90]. This inherited bone disease is caused by an autosomal dominant (in some patients, more severe, autosomal recessive) mutation and dysfunctional osteoclast cells. These skeletal radiographs have been misinterpreted and skeletal fluorosis diagnosed. This heterogeneous disorder has no connection to excess fluoride; it is a genetic abnormality in which osteoclasts are inefficient in the bone resorption. Those with dental fluorosis do not have excess prevalence of CKDmfo. The data do not support a connection between the existence of dental or skeletal fluorosis and CKDmfo.

In the bone micro milieu, an acidic medium is necessary to activate proteolytic enzymes to the cleavage of the bone matrix-collagen and dissociate calcium hydroxyapatite from the matrix (i.e., to remove older or micro cracks in the bone turnover physiological process). Osteopetrosis is caused by mutations of the carbonic anhydrase II gene [91] in osteoclasts and associated with osteopetrosis and renal tubular acidosis. This enzyme generates $\mathrm{H}^{+}$locally within the osteoclast-resorption pits that are essential for activating bone-resorbing enzymes [92]. The lack of acidification occurs due to abnormality of carbonic anhydrase II enzyme, causes defective bone resorption by osteoclasts. This leads to bones becoming radio-dense and heavy, due to unopposed bone formation [93] and the accumulation of a large quantity of divalent cations, which simulates skeletal fluorosis in radiographs.

\section{Observations and New Concepts}

In most of the CKDmfo-affected countries, a single causative etiological factor has not been identified $[4,6,10]$. In parts of China and the Balkans region in southern Europe, the disease is attributed to excess ingestion of aristolochic acid [52,94]; this is not confirmed and remains a controversial hypothesis. In Bangladesh and some parts of India, CKDu is thought to be caused by the consumption of groundwater containing geogenic arsenic $[95,96]$. However, many such patients do not present with renal failure but with bladder cancer [97]. In all other countries, including Sri Lanka and Mesoamerican countries, no definite cause has been established for CKDmfo.

\subsection{Geographical and Other Similarities of CKDmfo-Affected Regions and Countries}

Similarities and dissimilarities of $\mathrm{CKDu} / \mathrm{CKDmfo}$ in different countries (and regions within them) have been reported previously [13]. There are several commonalities in CKDmfo/CKDu-affected areas [6], including underprivileged populations with poor socioeconomic and educational conditions. Other similarities include geographical closeness to the equator, flat landscape, predominantly agriculture-based economies, and harsh climatic conditions (El Niño-like effects with a global warming-related average temperature increase of $\left.0.5^{\circ} \mathrm{C}\right)[4,6,10,16]$.

Based on commonalities and differences of CKDmfo/CKDu affected regions and countries, certain conclusions can be drawn to narrow the presumed, potential etiological factors $[6,10,12,16]$. While similarities are noteworthy, differences draw the attention to developing new hypotheses and directing future funding for research programs. Table 1 shows the similarities and differences between CKDmfo in Sri Lanka and CKDu in other countries.

As shown in Table 1, there are more similarities than dissimilarities in the fundamental facts related to CKDmfo [13]. 
Table 1. Geographic, socioeconomic, and cultural factors, the disease pattern, and the manifestation of CKDmfo in Sri Lanka versus CKDu in other countries- similarities and differences *.

\begin{tabular}{|c|c|c|}
\hline \multirow{2}{*}{ Factor and/or Condition } & \multicolumn{2}{|r|}{ Disease Status } \\
\hline & CKDmfo in Sri Lanka & CKDu in other Countries \\
\hline \multicolumn{3}{|l|}{ Similarities } \\
\hline First known manifestation of the disease & Mid-1990s & Mid-1970s \\
\hline Duration of exposure required & About 10 to 15 years & Approximately 8 to 10 years \\
\hline Those affected & Disadvantaged populations & Disadvantaged populations \\
\hline Economy & Emerging economy & Developing or emerging \\
\hline Potential source & $\begin{array}{l}\text { Contaminated water (food may indirectly } \\
\text { contribute) }\end{array}$ & Contaminated water \pm food \\
\hline Type of exposure to toxic agents & Environmental and occupational exposure & Environmental and occupational exposure \\
\hline Potential causes and factors & $\begin{array}{c}\text { Multiple factors with synergistic or additive } \\
\text { effects }\end{array}$ & Multiple factors causing chronic renal failure \\
\hline Working conditions & No safety precautions & No safety precautions \\
\hline Chronic dehydration & Highly prevalent: (climate + alcohol) & Highly prevalent (climate and harsh working conditions) \\
\hline Presence of hard water & Common across the affected regions & Common and widespread \\
\hline Drinking water & Insufficient quantities & Insufficient quantities \\
\hline Most-affected gender & Male (approximately 70\%) & Male (approximately $80 \%$ ) \\
\hline Economic status & High prevalence of poverty & Very high prevalence of poverty \\
\hline Access to modern healthcare & Poor (less than optimal) & Very poor (minimal) \\
\hline Access to nutritious food & Low & Very low \\
\hline Nutrition status & Approximately $70 \%$ malnourished & Approximately $80 \%$ malnourished \\
\hline Micronutrient malnutrition & Uniformly present & Uniformly present \\
\hline Landscape & Flat land with poor drainage & Flat land with poor drainage \\
\hline Closeness to the equator & Located just north of the equator & Both sides of the equator \\
\hline Relation to farming activities & $\begin{array}{l}\text { Local farming (significant proportion, mostly } \\
\text { daily wage earners); non farmers also affected }\end{array}$ & $\begin{array}{c}\text { Predominately commercial labours (e.g., sugarcane); also affects } \\
\text { individual farmer }\end{array}$ \\
\hline
\end{tabular}


Table 1. Cont.

\begin{tabular}{|c|c|c|}
\hline \multirow{2}{*}{ Factor and/or Condition } & \multicolumn{2}{|c|}{ Disease Status } \\
\hline & CKDmfo in Sri Lanka & CKDu in other Countries \\
\hline Bioaccumulation & Likely & Possible \\
\hline Evidence of genetic origin & None & None \\
\hline Climatic condition & $\begin{array}{l}\text { Prolonged dry spells with short period of } \\
\text { torrential rain }\end{array}$ & Dry spells alternating with flooding \\
\hline Family clusters are affected & Yes & Yes \\
\hline Drinking water source & Mostly shallow wells & Mostly shallow wells \\
\hline Iatrogenic causes & Unlikely & Unlikely \\
\hline \multicolumn{3}{|l|}{ Differences } \\
\hline Agricultural & Rice and vegetables & Cotton and sugarcane, and others \\
\hline Predominant agricultural economic base & Paddy and vegetable & Cotton, sugarcane, rice, and vegetables \\
\hline Type of communities affected & $\begin{array}{l}\text { Predominately agricultural communities; lesser } \\
\text { number from non-agricultural communities }\end{array}$ & Disease also present in non-agricultural communities \\
\hline Agrochemical overuse & Mostly fertilizer & Mostly pesticides \\
\hline Group most affected & Individual farm workers & Industrial farm workers \\
\hline Eutrophication of water & With phosphate & Rarely; occasionally nitrates \\
\hline Heavy metal in drinking water & Minimal or none (not consistent) & Present in some locations \\
\hline Presence of fluoride in water & Yes, but not uniformly & Heterogeneously present in most countries \\
\hline Detection of pesticide in drinking water & Virtually none & Common \\
\hline Affected younger population & Children rarely affected & Older children are affected \\
\hline Type of renal tissue affected & $\begin{array}{l}\text { Initially, predominantly affecting the } \\
\text { tubulointerstitial tissues }\end{array}$ & Affecting both glomerular and tubulointerstitial tissues \\
\hline Histologic type & Morphology, typical interstitial tubular nephritis & Interstitial nephritis; but may not be typical \\
\hline Proteinuria & Late occurrence & Early occurrence \\
\hline
\end{tabular}




\subsection{Effects of Diet and Malnutrition}

Poverty is widespread in CKDmfo-stricken regions in the affected countries. Because of the unaffordability of a balanced diet of nutritious foods, the lack of understanding of the importance of a balanced diet, and advertisement-driven habit changes, diets have markedly changed in these regions. Most people in CKDmfo-affected villages eat too little protein, healthy fat, and micronutrients; their diet predominantly (in excess of 90\%) consists of carbohydrates. Excess intake of fructose also can have negative effects on renal tubular function though fructokinase activity in the presence of chronic dehydration [45].

A significant proportion of energy in those who are affected with CKDmfo is derived from fructose. This excess ratio of intake fructose to the total carbohydrate content could enhance renal fructokinase activity and in the longer term could negatively affect renal functions [16,45]. Nevertheless, the potential contributions from such unwholesome diets to the genesis of CKDmfo/CKDu has not been investigated adequately. As a consequence of malnutrition, people become more vulnerable to acquire CKDmfo and other chronic diseases. This susceptibility is further aggravated by the lack of access to safe drinking water and safe sanitary facilities $[16,70,80]$.

\subsection{Intracellular Inclusion Bodies, Tubular Markers, and Chronic Kidney Disease}

Renal tubular inclusion bodies consist of granular, amorphous, non-membrane-bound material, without evidence of degeneration or necrosis in renal epithelial cells. Other studies have reported intracytoplasmic viral inclusion bodies, especially related to hantavirus, by electron microscopy, associated with the rough endoplasmic reticulum and Golgi cisternae [98].

Moreover, in vitro studies using a hypoxic model, reported that injured renal cells produce an increased number of exosomes that activate fibroblasts and secrete excess profibrotic growth factors such as type I collagen [99], $\alpha$-smooth muscle actin expression, and TGF- $\beta 1$ [100]. The combination of these can initiate interstitial tissue fibrosis that is seen in chronic kidney disease, especially CKDmfo. Extracellular vesicles also forms within the renal tubular cells that increase intracellular protective compounds, such as transcriptional factor 3 (AFT3) [101], fetuin-A [102], neutrophil gelatinase-associated lipocalin (NGAL) protein [10], aquaporin-1 [103], and AQ1 [101]; these can be used as biomarkers to identify early renal tubular cell damage.

\subsection{Ion Interactions and In Vivo Formation of Apatite}

$\mathrm{Mg}^{2+}$ is the fourth most abundant mineral in the body. Generally, in vivo, magnesium counteracts the effects of calcium. Hydroxyapatite crystals predominantly contain $\mathrm{Ca}^{2+}$ and $\mathrm{PO}_{4}{ }^{3-}[104,105]$. In addition to the dietary intake, physiological secretions into the intestinal tract also contain $\mathrm{Ca}^{2+}$ and $\mathrm{Mg}^{2+}$. In the intestine, many nephrotoxic substances that enter the gut via water, beverages, and diet, bind to divalent cations $\left(\mathrm{Ca}^{2+}\right.$ and $\mathrm{Mg}^{2+}$ ) and lessen their absorption; an inherent protective evolutionary mechanism to minimize toxicity. Therefore, the ion-ion interactions and additive or synergistic effects of minerals and toxins need to be examined closely [106-108].

With reference to these pollutants, the bioavailability of compounds (e.g., $\mathrm{HMs}$, fluoride, $\mathrm{Ca}^{2+}$, $\mathrm{Mg}^{2+}$, etc.), which in part depend on solubility and the $\mathrm{pH}$ [109], is what is important. Temporary hardness of water is common across the entire NCP region. Despite this, CKDmfo affects only certain regions and villages. For example, when the temporary hardness of water $\left(\mathrm{CaCO}_{3}\right.$ equivalent $)$ exceeds $200 \mathrm{mg}$ of calcium equivalent, boiling water will precipitate $\mathrm{F}^{-}$as $\mathrm{CaF}_{2}$ and $\mathrm{MgF}_{2}$, significantly reducing the bioavailable $\mathrm{F}^{-}$. Moreover, fluoride-bearing mineral nanoparticles are harder and more stable to degradation in vitro and in vivo. A few examples of nanomineral particles [110,111] are illustrated side by side in Figure 4 to demonstrate the surface and structural dissimilarities of hydroxyapatite and fluorapatites. 


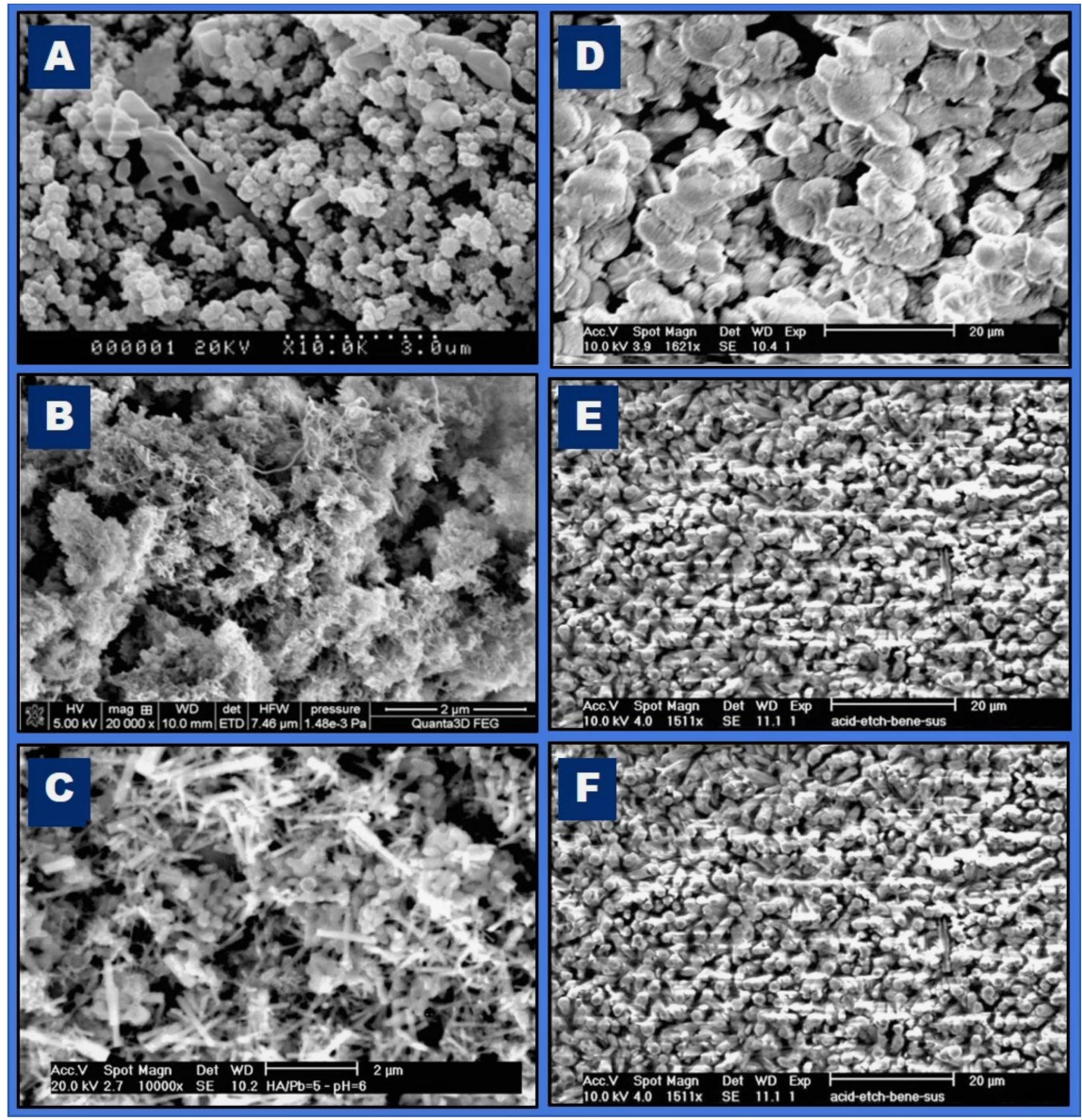

Figure 4. Examples of hydroxyapatite and fluorapatites demonstrating the contrast. Compared with (A-C), fluorapatites (D-E) are harder and structurally more defined (adapted from Czajka-Jakubowska et al. 2009 [110], Arnich et al. 2003 [112], and Skwarek et al. 2018 [111]).

\subsection{Nanominerals Causing Pathology}

Calcium phosphate $\mathrm{Ca}_{2}\left(\mathrm{PO}_{4}\right)_{3}$ apatite is present in nature, in vivo it occurs in combination with other elements. In hydroxyapatite, calcium can be substituted with other divalent cations such as $\mathrm{Pb}^{2+}, \mathrm{Cu}^{2+}, \mathrm{Cd}^{2+}$, or $\mathrm{Zn}^{2+}$, and phosphate can be supplanted by anions, such as $\mathrm{CO}_{3}{ }^{2-}, \mathrm{SO}_{4}{ }^{2-}, \mathrm{AsO}_{4}{ }^{3}$, or $\mathrm{SiO}_{4}{ }^{4-}$. The surfaces govern the solubility of mineral apatite $\left(\mathrm{M}_{5}\left(\mathrm{PO}_{4}\right)_{3} \mathrm{X}\right)$, isomorphic capacity, and numerous potential substitutions of ions [113]; thus, the composition of the surface is important [114]. In this regard, the surface layer of hydroxyapatite is markedly different from that of fluorapatite; the dissolvability of the latter is less, making it more stable.

The solubility of calcium phosphate mineral hydroxyapatite, $\mathrm{Ca}_{5}\left(\mathrm{PO}_{4}\right)_{3} \mathrm{OH}$, increases in acidic $\mathrm{pH}$ lower than 5, as in urine, which is reduced in fluorapatite [114]. The chronic dehydration of outdoor workers in CKDmfo-affected regions and the mentioned characteristics create an internal environment favourable for the precipitation of nanominerals in renal tubular tissues. These include calcium phosphate hydroxyapatite as well as $\mathrm{CaOX}$ and urate precipitates, based on their tissue and tubular fluid supersaturations [63].

However, solubility is retarded when $\mathrm{F}^{-}$is incorporated to these nanoparticles. What is important is the in vivo solubility/stability, $\mathrm{pH}$, and bioavailability of elements in precipitation of mineral nanoparticles. This is important in soft tissue calcification in kidneys as well as in the vascular walls. Moreover, findings suggest that calcium phosphate, fluorapatite $\left[\mathrm{Ca}_{10}\left(\mathrm{PO}_{4}\right)_{6}(\mathrm{~F})\right]$ nanoparticles can be a focus for intra-renal calcification, not only in formation of nanotubes but also that of renal stones. However, the relevance of such tubular nanoparticles to CKDmfo is not fully understood. 
Nanoparticles can have significant adverse effects on human cells. These harmful effects depend on several factors, including exposure, comorbidities, and the composition, size and the shape, accumulation rate and the ability to grow, and electromagnetic properties of nanoparticles, and the genetic susceptibility [115].

Animal and human studies reported a less efficient removal of inhaled nanoparticles, than micro or macro particles by macrophages in the lung [115]. Because of the minute size of nanoparticles, these have the ability to penetrate biological membranes and enter into cells. Moreover, nanoparticles can translocate through the circulatory and the lymphatic systems to other tissues. These can disrupt cellular function, causing inflammation and increase oxidative stress (alter cellular redox balance toward oxidation), causing cell death [115]. This concept is illustrated in Figure 5.

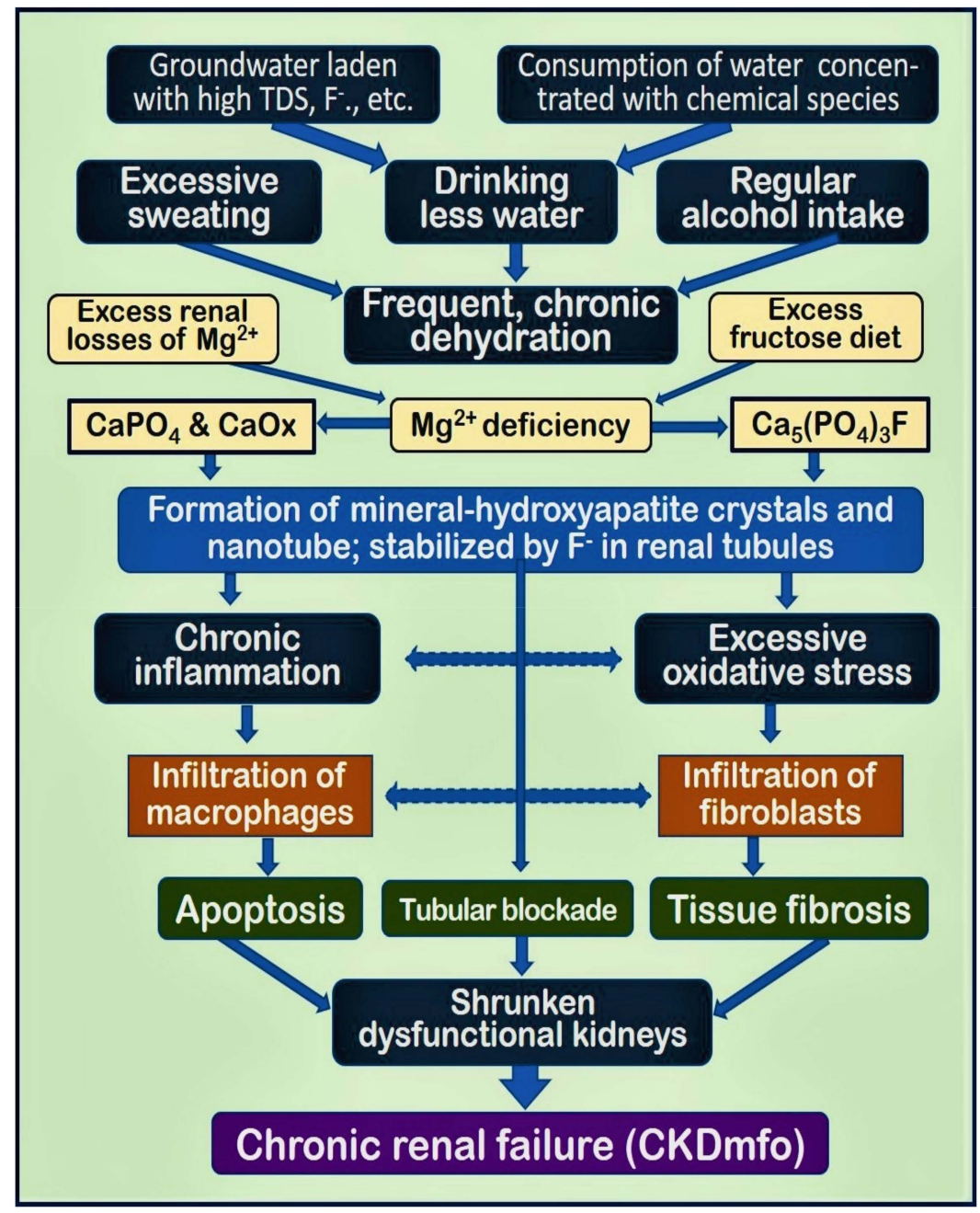

Figure 5. Causative pathways for nanotube and nanocrystal formation and developing CKDmfo. TDS $=$ total dissolved substances $\left(\mathrm{Ca}^{2+}\right.$ and $\mathrm{PO}_{4}{ }^{3-}, \mathrm{Mg}^{2+}$, etc. $) ; \mathrm{CaPO} 4=$ calcium phosphate; $\mathrm{CaOx}=$ calcium oxalate; $\mathrm{Mg}^{2+}=$ magnesium; $\mathrm{F}^{-}=$fluoride.

Renal tubular failure can occur after excess intake of toxic elements or HM intoxication, such as with itai-itai disease through water pollution with cadmium [116]. Cadmium toxicity also causes Fanconi syndrome and osteomalacia, whereas arsenic causes renal impairment and bladder cancer [117]. Cadmium and arsenic, however, are not present in measurable amounts and thus are unlikely to be involved in CKDmfo [68,118]. 


\subsection{Other Factors to Consider}

The burning of coal is an important and inexpensive energy source in many countries. Because of the lack of safety precautions, it contributes to environmental pollution, including the spread of fluorine and heavy metals through wind and rainfall. These contaminants can reach sites far from the location of the power plant, which is another mode of water contamination [109,119-121]. In fact, there is a large coal-fired power plant located north of the NCP from which the wind brings pollutants to the CKDmfo-affected region. Similar contaminations occur with mining, drilling, and fracking, but they are not present in these regions.

When renal functions deteriorate, many substances that otherwise would have been eliminated via urine accumulate in the blood and the body. These include HMs, arsenic, and fluoride, and their toxicity is enhanced. Because these toxic substances are retained in the body, the interpretations of their concentration as measured in tissue samples, blood, and urine cannot be relied upon to correlate to disease. What matters is the availability of the bioavailable mineral components to precipitate under the right concentration and conditions.

In persons with impaired renal function, toxic substances such as HMs, fluoride, and arsenic invariably are higher in serum and tissues (and may be low in urine), yet those levels have no correlation with the status of disease or disease cause [83]. Although suggestions of viral [122,123] and genetic aetiology exist, there are no established scientific data for such $[6,10]$.

All CKDmfo/CKDu studies that were conducted well, with larger sample sizes that followed standard sample collection guidelines for water and food collection and storage and analysis methods in Sri Lanka, have failed to detect meaningful amounts of any nephrotoxic agents [5,14,124], including using statistically validated sampling methods in identifying the postulated substances $[5,6,10,12,14,16,124]$.

\subsection{Explanations of Why Wet Zonal Regions are Spared of CKDmfo}

Despite the presence of the fluoride belt extending into the northern parts of the wet zone and the intermediate zones in the central and eastern parts of the country, CKDmfo was not prevalent markedly in those regions of Sri Lanka until recently. It is unknown whether this is attributable to nonoptimal conditions with reference to other essential components, including the critical levels of fluoride needed to cause CKDmfo [107] and/or larger numbers of families migrating to the south (wet) part of the country, escaping from the CKDmfo-affected regions.

The people living in the wet zone in Sri Lanka have similar use of agrochemicals (i.e., fertilizers and pesticides) and similar education, culture, social, and eating and drinking habits as do those drinking water from shallow wells, but the prevalence of CKDmfo in the wet zone is minimal. Key differences in the southern regions are lack of tube wells and less poverty and malnutrition, and most importantly, these shallow wells are connected with underground flowing water sources. Further, dehydration is much less. In addition, the underground aquifer system, drainage, and soil conditions and some rock formations are different between the two regions.

The wet zone has significantly higher rainfall extending throughout the year with no interim extensive periods of drought; better soil drainage; and a different underground drainage pattern compared with the NCP. Wet zone residents also have better socioeconomic conditions, less malnutrition, and drinking water is soft with very little fluoride. Although these sets of conditions seem protective, one needs to investigate the additional component(s) to induce CKDmfo, present in NCP that are absent in the wet zone. Thus, using a subtraction variable in these two regions, it should be possible to narrow the causative factors.

A broad-based research program should be carried out to identify the "absent factor in the wet zone" that protects villagers in the south, wet region from getting the disease. Several major rivers originate from the hill country in Sri Lanka and flow across the entire country; such water is equally contaminated. The longest river, the Mahaweli, predominantly flows through the NCP and a part of the Uva province. Therefore, contrary to the beliefs of some, the water originating from the hill country 
is unlikely to be a major factor contributing to the genesis of this disease. The proposed, multiple key factors (multifactorial aetiology) and mechanisms causing CKDmfo is illustrated in the Figure 6.

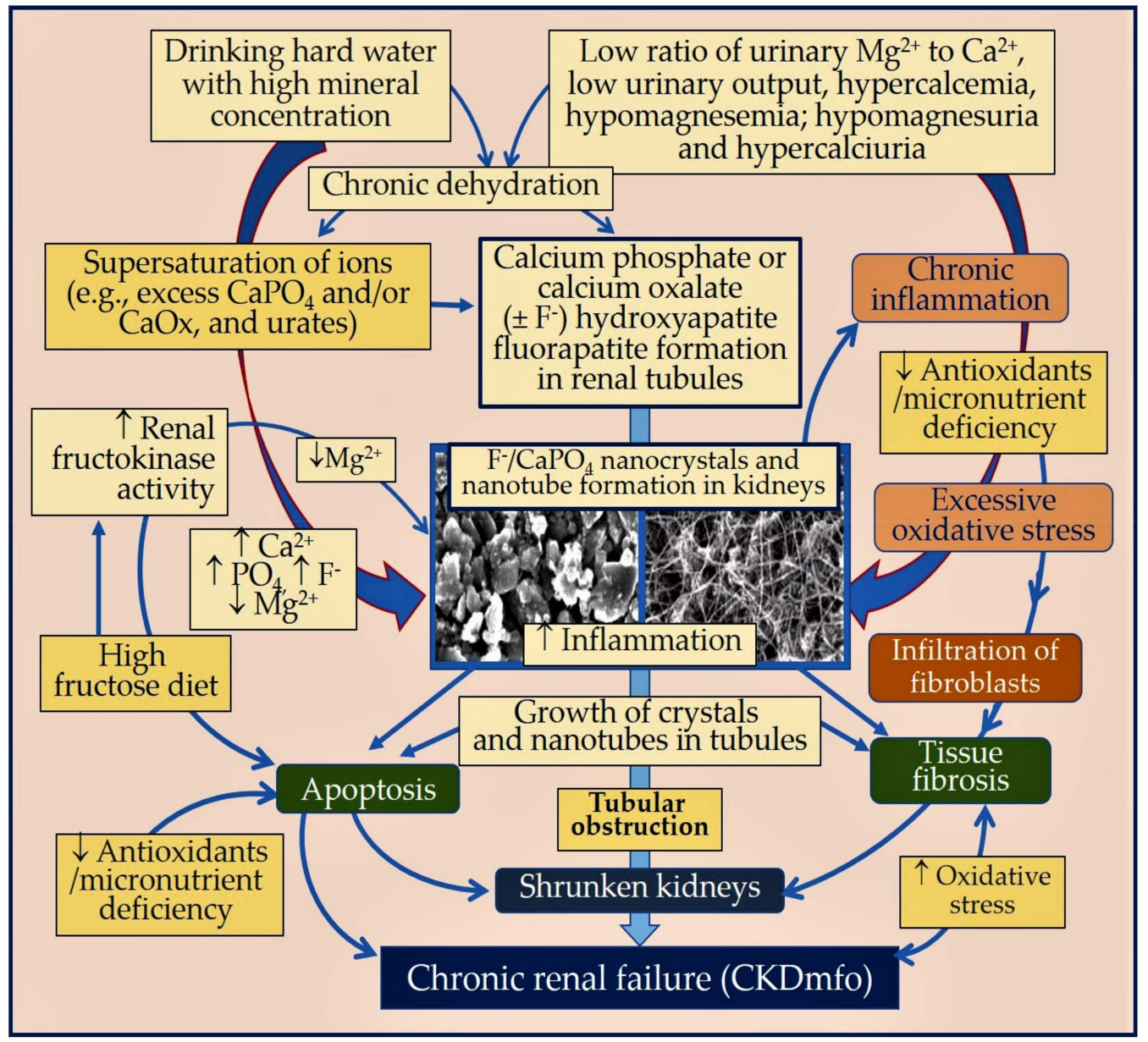

Figure 6. Concept diagram illustrating the cycle of development of nanocrystals and nanominerals in renal tubular cell and in tubules. Texts in light yellow boxes illustrate the basic conditions and multiple components, setting the stage for hydroxyapatite formation. Whereas, texts in the darker coloured boxes indicate the essential steps and conditions needed for nanomineral formation, chronic inflammation, tubular blockade, cellular apoptosis, fibrosis, and developing chronic renal failure-CKDmfo.

\section{Discussion}

CKDmfo/CKDu used to be confined to geographically demarcated areas in affected countries. However, in recent years, it has been expanding outside its traditional boundaries. The patterns of expansion of the disease prevalence provide opportunities to explore the unique contributions of environmental and geogenic factors, including geochemistry and water pollution, that may contribute to the disease. In addition, it is essential to study the bioavailable components, ion interactions, and effects of multiple factors that trigger the onset and exacerbate existing multi-factorial disease, rather than studying factors in isolation.

Other plausible pathways are HMs, such as cadmium, causing direct renal tubular cell toxicity [37,40] and fluoride initiating caspase-mediated DNA damage leading to renal cell apoptosis [42,43]. Because fluoride is the most electronegative element in the Hofmeister series and a highly reactive anion (i.e., fluoride is highly reactive with other substances), it cannot act by itself. However, given the right conditions, fluoride reacts and combines with cations, which enhances or reduces its toxicity.

Given available data, it is highly likely that extended exposure to moderate concentrations (perhaps less than the MAL) of nephrotoxins or components normally present in blood working 
synergistically because of certain changes in conditions, such as the formation of nanotubes and crystals within the renal tubules, is the cause of renal tubular toxicity [36,37]. These compounds by themselves are not classic nephrotoxins, but when combined, they can cause renal tubular toxicity.

One way forward is to carry out geochemical, soil, and water quality studies from the CKDmfo-affected villages in comparison with data obtained from non-affected villages in the NCP and from the wet zone, not only to identify the causative factor(s) but also to identify the "absent factor" that might prevent the manifestation of this fatal disease in other regions. However, water sample collections must be standardized and taken at the end of the dry season. Future research should explore tubular spaces and ultra-tubular structural details using modern scanning and transmission electron microscopy to examine the possible intra- and extra-cellular pathologies, such as inclusion bodies, nanotubes, and nanocrystals, especially those containing calcium phosphate apatite.

Self-harming behaviour, together with poverty-associated micronutrient malnutrition, undesirable changes in dietetic patterns, and chronic exposure to low levels of nephrotoxins over a prolonged period associated with chronic dehydration perpetuate harmful conditions in vivo. The effects of recurrent dehydration on renal and tubular cell function are compounded by daily alcohol intake and ingestion of water containing a higher concentration of bioavailable minerals and fluoride. Meanwhile, because of the climatic changes, water hardness and total dissolved solids in the water as well as water $\mathrm{F}^{-}$contents in CKDmfo-affected regions continue to increase.

Regular alcohol intake also reduces the $\mathrm{Mg}^{2+}$ in body stores and the circulation (hypomagnesemia) [125]. The long-term use of proton pump inhibitors impairs intestinal magnesium absorption, and this can cause hypomagnesemia [126,127]. In addition, other drugs and toxins can cause hypomagnesemia by impairment of the renal tubular magnesium reabsorption in the thick ascending limb and/or the distal convoluted tubule [128,129]. These conditions could increase the risks and vulnerability of people to the development of CKDmfo. Moreover, low $\mathrm{Mg}$ is associated with hypertension and vascular calcification, and increased risks for cardiovascular diseases and mortality, especially in those with CKD [130].

\section{Conclusions}

Hydroxyapatite nanominerals are formed in renal tubular cells and in tubular spaces, with chronic ingestion of excess species of $\mathrm{Ca}^{2+}$ and $\mathrm{PO}_{4}{ }^{3-}$ in hardwater and fluoride, in the presence of repeated cycles of dehydration producing concentrated urine. In addition to hydroxy- and oxalate-apatite, $\mathrm{F}^{-}$forms fluoroapatite, which is more stable and resistant to degradation, allowing a slow growth of crystals in vivo. Antioxidant and micronutrient deficiencies further increase the vulnerability to CKDmfo.

The exact cause of CKDmfo/CKDu has not been established; the mentioned conditions with nanomineral formation, however, are a prerequisite for the development of CKDmfo. Thus, the provision of adequate amounts of clean water (for drinking) and educating people to avoid repeated cycles of dehydration are essential components in preventing this deadly renal disease. Overall data do not support agriculture (fertilizers, pesticides) or nephrotoxins, such as algal toxins or heavy metals or a genetic aetiology of causing this environmentally induced deadly disease, CKDmfo.

Author Contributions: Authors equally contributed to this work. C.B.D. is an Emeritus Professor of Geology specializing in geochemistry and the former Head of Department of Geology, University of Peradeniya, Sri Lanka. He is also a former Director of the National Institute of Fundamental Studies in Sri Lanka. S.J.W. is a professor of medicine. For more than two decades, he has been studying the issues related to water contamination, including fluoride issues related to escalating chronic diseases, with the focus on disease prevention. This article is in part based on data collected over several years through the charitable foundation [https://wimalawansa.org/ community_projects] that has been engaged in educating the public on the prevention of water and air pollution, alleviation of malnutrition, holistic approach to disease prevention, use of inclusive agricultural practices, and the provision of clean water in preventing CKDmfo. All authors have read and agreed to the published version of the manuscript

Funding: This research received no external funding. 
Conflicts of Interest: The authors declare no conflicts of interest. This research received no grant funding or writing assistance from agencies in the public, commercial, or not-for-profit sectors.

\section{References}

1. Hajat, C.; Stein, E. The global burden of multiple chronic conditions: A narrative review. Prev. Med. Rep. 2018, 12, 284-293. [CrossRef] [PubMed]

2. Ryu, S.; Chang, Y.; Woo, H.Y.; Lee, K.B.; Kim, S.G.; Kim, D.I.; Kim, W.S.; Suh, B.S.; Jeong, C.; Yoon, K. Time-dependent association between metabolic syndrome and risk of CKD in Korean men without hypertension or diabetes. Am. J. Kidney Dis. 2009, 53, 59-69. [CrossRef] [PubMed]

3. Glaser, J.; Weiss, I.; La Isla, F. CKDu: Strategies for saving lives now. Med. Rev. 2014, 16, 81-82.

4. Wimalawansa, S.J. Escalating Chronic Kidney Diseases in Sri Lanka: Causes, Solutions and recommendations. Environ. Health Prev. Med. 2014, 19, 375-394. [CrossRef] [PubMed]

5. Jayatilake, N.; Mendis, S.; Maheepala, P.; Mehta, F.R. Chronic kidney disease of uncertain aetiology: Prevalence and causative factors in a developing country. BMC Nephrol. 2013, 14, 180. [CrossRef] [PubMed]

6. Wimalawansa, S.J. The role of ions, heavy metals, fluoride, and agrochemicals: Critical evaluation of potential aetiological factors of chronic kidney disease of multifactorial origin (CKDmfo/CKDu) and recommendations for its eradication. Environ. Geochem. Health 2016, 38, 639-678. [CrossRef]

7. Dunuweera, R.; Shimomura, R.M.G.; Priyankarage, J.V.; Jayasingha, P.; Wimalawansa, S.J. Chronic kidney disease of multifunctional origin (CKDmfo) prevailing in Sri Lanka: Re-evaluated. World J. Pharm. Res. 2017, 6, 33-66.

8. Diyabalanage, S.; Abekoon, S.; Watanabe, I.; Watai, C.; Ono, Y.; Wijesekara, S.; Guruge, K.S.; Chandrajith, R. Has irrigated water from Mahaweli River contributed to the kidney disease of uncertain etiology in the dry zone of Sri Lanka? Environ. Geochem. Health 2016, 38, 679-690. [CrossRef]

9. Wimalawansa, S.J. Chronic Kidney Disease in Rajarata, Worse than Tsunami. Sunday Observer. 26 November 2013. Available online: http://www.sundayobserver.lk/2013/11/24/fea06.asp (accessed on 20 November 2019).

10. Wimalawansa, S.J. Molecular and cellular toxicity of fluoride in mystery, tubulointerstitial chronic kidney disease: A systematic review. Rev. Environ. Sci. Biotechnol. 2019, in press. [CrossRef]

11. Wickremasinghe, A.R.; Peiris-John, R.J.; Wanigasuriya, K.P. Chronic kidney disease of unknown aetiology in the North Central Province of Sri Lanka: Trying to unravel the mystery. Ceylon Med. J. 2011, 56, 143-146. [CrossRef]

12. Wimalawansa, S.A.; Wimalawansa, S.J. Agrochemical-Related Environmental Pollution: Effects on Human Health. Glob. J. Biol. Agric. Health Sci. 2014, 3, 72-83.

13. Wimalawansa, S.J.; Wimalawansa, S.A. Chronic kidney disease of multifactorial origin (CKDmfo) in Sri Lanka: Escalating incidence and long-term survival estimates. J. Nephrol. Urol. Res. 2015, 22, 1-17.

14. Chandrajith, R.; Nanayakkara, S.; Itai, K.; Aturaliya, T.N.; Dissanayake, C.B.; Abeysekera, T.; Harada, K.; Watanabe, T.; Koizumi, A. Chronic kidney diseases of uncertain etiology (CKDue) in Sri Lanka: Geographic distribution and environmental implications. Environ. Geochem. Health 2011, 33, 267-278. [CrossRef] [PubMed]

15. Bandara, J.M.; Senevirathna, D.M.; Dasanayake, D.M.; Herath, V.; Bandara, J.M.; Abeysekara, T.; Rajapaksha, K.H. Chronic renal failure among farm families in cascade irrigation systems in Sri Lanka associated with elevated dietary cadmium levels in rice and freshwater fish (Tilapia). Environ. Geochem. Health 2008, 30, 465-478. [CrossRef] [PubMed]

16. Wimalawansa, S.J. Agrochemicals and chronic kidney disease of multifactorial origin: Environmentally induced occupational exposure disease. Int. J. Nephrol. Kidney Fail. 2015, 1, 1-9. [CrossRef]

17. Wimalawansa, S.J. Effect of water hardness on non-communicable diseases including chronic kidney disease of multifactorial origin (CKDmfo/CKDuo). J. Environ. Health Sci. Eng. 2016, 2, 1-11. [CrossRef]

18. Faye, M.; Lemrabott, A.T.; Cisse, M.M.; Fall, K.; Keita, Y.; Ngaide, A.A.; Mbaye, A.; Fary Ka, E.H.; Niang, A.; Kane, A.; et al. Prevalence and risk factors of chronic kidney disease in an african semi-urban area: Results from a cross-sectional survey in Gueoul, Senegal. Saudi J. Kidney Dis. Transpl. 2017, 28, 1389-1396. [CrossRef]

19. Abdulkader, R.; Burdmann, E.A.; Lebrao, M.L.; Duarte, Y.A.O.; Zanetta, D.M.T. Aging and decreased glomerular filtration rate: An elderly population-based study. PLoS ONE 2017, 12, e0189935. [CrossRef] 
20. Noble, A.; Amerasinghe, P.; Manthrithilake, H.; Arasalingam, S. Review of Literature on Chronic Kidney Disease of Unknown Etiology (CKDu) in Sri Lanka; International Water Management Institute (IWMI): Colombo, Sri Lanka, 2014.

21. Wimalawansa, S.A.; Wimalawansa, S.J. Environmentally induced, occupational diseases with emphasis on chronic kidney disease of multifactorial origin affecting tropical countries. Ann. Occup. Environ. Med. 2016, 28, 33. [CrossRef]

22. Orantes, C.M. Clinical Characterization and Histopathology of Nephropathy in Salvadorian Agricultural Communities. In Proceedings of the International Conference on Saptial Ecotoxicology, San Salvador, El Salvador, 29 October 2013.

23. Wijetunge, S.; Ratnatunga, N.V.; Abeysekera, D.T.; Wazil, A.W.; Selvarajah, M.; Ratnatunga, C.N. Retrospective analysis of renal histology in asymptomatic patients with probable chronic kidney disease of unknown aetiology in Sri Lanka. Ceylon Med. J. 2013, 58, 142-147. [CrossRef]

24. Wyne, K.; Wimalawansa, S.J. Screening and Diagnosis of Chronic Tubular Kidney Disease of Multi-Factorial Origin. In Proceedings of the 5th International Conference on Sustainable Built Environment, Environment Pollution of Prevention of CKD-mfo in Sri Lanka, Kandy, Sri Lanka, 11-13 October 2014; pp. 11-13.

25. Wimalawansa, S.J. Prevention of CKD of multi-factorial Origin (CKD-mfo): Issues, gravity, \& the importance of early diagnosis. In Proceedings of the 5th International Conference on Sustainable Built Environment, Environment Pollution of Prevention of CKD-mfo in Sri Lanka, Kandy, Sri Lanka, 11-13 October 2014; pp. 22-26.

26. Nanayakkara, S.; Komiya, T.; Ratnatunga, N.; Senevirathna, S.T.; Harada, K.H.; Hitomi, T.; Gobe, G.; Muso, E.; Abeysekera, T.; Koizumi, A. Tubulointerstitial damage as the major pathological lesion in endemic chronic kidney disease among farmers in North Central Province of Sri Lanka. Environ. Health Prev. Med. 2012, 17, 213-221. [CrossRef] [PubMed]

27. Wimalawansa, S.J. Escalating Chronic Kidney Diseases in Sri Lanka: Causes, Solutions and recommendations-Update and responses. Environ. Health Prev. Med. 2015, 20, 152-157. [CrossRef] [PubMed]

28. D'Amico, G.; Bazzi, C. Pathophysiology of proteinuria. Kidney Int. 2003, 63, 809-825. [CrossRef] [PubMed]

29. Yokoyama, T.; Kamijo-Ikemori, A.; Sugaya, T.; Hoshino, S.; Yasuda, T.; Kimura, K. Urinary excretion of liver type fatty acid binding protein accurately reflects the degree of tubulointerstitial damage. Am. J. Pathol. 2009, 174, 2096-2106. [CrossRef]

30. Kamijo-Ikemori, A.; Ichikawa, D.; Matsui, K.; Yokoyama, T.; Sugaya, T.; Kimura, K. Urinary L-type fatty acid binding protein (L-FABP) as a new urinary biomarker promulgated by the Ministry of Health, Labour and Welfare in Japan. Jpn. J. Clin. Pathol. 2013, 61, 635-640.

31. Li, Y.; Zhu, M.; Xia, Q.; Wang, S.; Qian, J.; Lu, R.; Che, M.; Dai, H.; Wu, Q.; Ni, Z.; et al. Urinary neutrophil gelatinase-associated lipocalin and L-type fatty acid binding protein as diagnostic markers of early acute kidney injury after liver transplantation. Biomarkers 2012, 17, 336-342. [CrossRef]

32. Liu, S.; Che, M.; Xue, S.; Xie, B.; Zhu, M.; Lu, R.; Zhang, W.; Qian, J.; Yan, Y. Urinary L-FABP and its combination with urinary NGAL in early diagnosis of acute kidney injury after cardiac surgery in adult patients. Biomarkers 2013, 18, 95-101. [CrossRef]

33. Doi, K.; Noiri, E.; Sugaya, T. Urinary L-type fatty acid-binding protein as a new renal biomarker in critical care. Curr. Opin. Crit. Care 2010, 16, 545-549. [CrossRef]

34. Jimenez-Cordova, M.I.; Cardenas-Gonzalez, M.; Aguilar-Madrid, G.; Sanchez-Pena, L.C.; Barrera-Hernandez, A.; Dominguez-Guerrero, I.A.; Gonzalez-Horta, C.; Barbier, O.C.; Del Razo, L.M. Evaluation of kidney injury biomarkers in an adult Mexican population environmentally exposed to fluoride and low arsenic levels. Toxicol. Appl. Pharm. 2018, 352, 97-106. [CrossRef]

35. Wimalawansa, S.J. Public health interventions for chronic diseases: Cost-benefit modelizations for eradicating chronic kidney disease of multifactorial origin from tropical countries. Heliyon 2019, in press. [CrossRef]

36. Garcon, G.; Leleu, B.; Marez, T.; Zerimech, F.; Haguenoer, J.M.; Furon, D.; Shirali, P. Biomonitoring of the adverse effects induced by the chronic exposure to lead and cadmium on kidney function: Usefulness of alpha-glutathione S-transferase. Sci. Total Environ. 2007, 377, 165-172. [CrossRef] [PubMed]

37. Phuc, H.D.; Kido, T.; Oanh, N.T.P.; Manh, H.D.; Anh, L.T.; Oyama, Y.; Okamoto, R.; Ichimori, A.; Nogawa, K.; Suwazono, Y.; et al. Effects of aging on cadmium concentrations and renal dysfunction in inhabitants in cadmium-polluted regions in Japan. J. Appl. Toxicol. 2017, 37, 1046-1052. [CrossRef] [PubMed] 
38. Dharmaratne, R.W. Fluoride in drinking water and diet: The causative factor of chronic kidney diseases in the North Central Province of Sri Lanka. Environ. Health Prev. Med. 2015, 20, 237-242. [CrossRef] [PubMed]

39. Wimalawansa, S.; Wimalawansa, S.J. Protection of watersheds, and control and responsible use of fertiliser to prevent phosphate eutrophication ofreservoirs. Int. J. Res. Environ. Sci. 2015, 1, 1-18.

40. Vesey, D.A. Transport pathways for cadmium in the intestine and kidney proximal tubule: Focus on the interaction with essential metals. Toxicol. Lett. 2010, 198, 13-19. [CrossRef]

41. Wimalawansa, S.J. Vitamin D deficiency: Effects on oxidative stress, epigenetics, gene regulation, and aging. Biology (Basel) 2019, 8, 30. [CrossRef]

42. Song, C.; Fu, B.; Zhang, J.; Zhao, J.; Yuan, M.; Peng, W.; Zhang, Y.; Wu, H. Sodium fluoride induces nephrotoxicity via oxidative stress-regulated mitochondrial SIRT3 signaling pathway. Sci. Rep. 2017, 7, 672. [CrossRef]

43. Song, G.H.; Gao, J.P.; Wang, C.F.; Chen, C.Y.; Yan, X.Y.; Guo, M.; Wang, Y.; Huang, F.B. Sodium fluoride induces apoptosis in the kidney of rats through caspase-mediated pathways and DNA damage. J. Physiol. Biochem. 2014, 70, 857-868. [CrossRef]

44. Herath, S.; Ayala, H.M.; Kawakami, T.; Nagasawa, S.; Serikawa, Y.; Motoyama, A.; Chaminda, G.G.; Weragoda, S.K.; Yatigammana, S.K.; Amarasooriya, A.A.G.D. Arsenic, cadmium, lead, and chromium in well water, rice, and human urine in Sri Lanka in relation to chronic kidney disease of unknown etiology. J. Water Health 2018, 16, 212-222. [CrossRef]

45. Roncal Jimenez, C.A.; Ishimoto, T.; Lanaspa, M.A.; Rivard, C.J.; Nakagawa, T.; Ejaz, A.A.; Cicerchi, C.; Inaba, S.; Le, M.; Miyazaki, M.; et al. Fructokinase activity mediates dehydration-induced renal injury. Kidney Int. 2014, 86, 294-302. [CrossRef]

46. Mohamed, N.E. The Role of Calcium in Ameliorating the Oxidative Stress of Fluoride in Rats. Biol. Trace Elem. Res. 2016, 170, 128-144. [CrossRef] [PubMed]

47. Barnett, L.M.A.; Cummings, B.S. Nephrotoxicity and Renal Pathophysiology: A Contemporary Perspective. Toxicol. Sci. 2018, 164, 379-390. [CrossRef] [PubMed]

48. Nanayakkara, S.; Senevirathna, S.T.; Karunaratne, U.; Chandrajith, R.; Harada, K.H.; Hitomi, T.; Watanabe, T.; Abeysekera, T.; Aturaliya, T.N.; Koizumi, A. Evidence of tubular damage in the very early stage of chronic kidney disease of uncertain etiology in the North Central Province of Sri Lanka: A cross-sectional study. Environ. Health Prev. Med. 2012, 17, 109-117. [CrossRef] [PubMed]

49. Zangeneh, F.; Clarke, B.L.; Hurley, D.L.; Watts, N.B.; Miller, P.D. Chronic Kidney Disease-Mineral and Bone Disorders (CKD-MBDs): What the Endocrinologist Needs to Know. Endocr. Pract. 2014, 20, 500-516. [CrossRef] [PubMed]

50. Ulinski, T.; Sellier-Leclerc, A.L.; Tudorache, E.; Bensman, A.; Aoun, B. Acute tubulointerstitial nephritis. Pediatr. Nephrol. 2012, 27, 1051-1057. [CrossRef] [PubMed]

51. Silva, F.G. Chemical-induced nephropathy: A review of the renal tubulointerstitial lesions in humans. Toxicol. Pathol. 2004, 32 (Suppl. 2), 71-84. [CrossRef]

52. Grollman, A.P.; Jelakovic, B. Role of environmental toxins in endemic (Balkan) nephropathy. October 2006, Zagreb, Croatia. J. Am. Soc. Nephrol. 2007, 18, 2817-2823. [CrossRef]

53. Futrakul, N.; Futrakul, P. Urgent call for reconsideration of chronic kidney disease. World J. Nephrol. 2012, 1, 155-159. [CrossRef]

54. Chiang, C.K.; Tanaka, T.; Nangaku, M. Dysregulated oxygen metabolism of the kidney by uremic toxins: Review. J. Ren. Nutr. 2012, 22, 77-80. [CrossRef]

55. Knochel, J.P.; Dotin, L.N.; Hamburger, R.J. Heat stress, exercise, and muscle injury: Effects on urate metabolism and renal function. Ann. Intern. Med. 1974, 81, 321-328. [CrossRef]

56. Roncal-Jimenez, C.; Garcia-Trabanino, R.; Barregard, L.; Lanaspa, M.A.; Wesseling, C.; Harra, T.; Aragon, A.; Grases, F.; Jarquin, E.R.; Gonzalez, M.A.; et al. Heat Stress Nephropathy From Exercise-Induced Uric Acid Crystalluria: A Perspective on Mesoamerican Nephropathy. Am. J. Kidney Dis. 2016, 67, 20-30. [CrossRef] [PubMed]

57. Garcia-Trabanino, R.; Jarquin, E.; Wesseling, C.; Johnson, R.J.; Gonzalez-Quiroz, M.; Weiss, I.; Glaser, J.; Jose Vindell, J.; Stockfelt, L.; Roncal, C.; et al. Heat stress, dehydration, and kidney function in sugarcane cutters in El Salvador-A cross-shift study of workers at risk of Mesoamerican nephropathy. Environ. Res. 2015, 142, 746-755. [CrossRef] [PubMed] 
58. Coe, F.L.; Evan, A.; Worcester, E. Kidney stone disease. J. Clin. Investig. 2005, 115, 2598-2608. [CrossRef] [PubMed]

59. Tiselius, H.G. The role of calcium phosphate in the development of Randall's plaques. Urolithiasis 2013, 41, 369-377. [CrossRef]

60. Ho, S.P.; Chen, L.; Allen, F.I.; Hsi, R.S.; Shimotake, A.R.; Wiener, S.V.; Stoller, M.L. Architecture-Guided Fluid Flow Directs Renal Biomineralization. Sci Rep. 2018, 8, 14157. [CrossRef]

61. Verma, R.; Niraimathi, M.; Prasad, P.; Agrawal, V. Dihydroxyadenine crystal-induced nephropathy presenting with rapidly progressive renal failure. Kidney Res. Clin. Pract. 2018, 37, 287-291. [CrossRef]

62. Larsen, C.P.; Bell, J.M.; Harris, A.A.; Messias, N.C.; Wang, Y.H.; Walker, P.D. The morphologic spectrum and clinical significance of light chain proximal tubulopathy with and without crystal formation. Mod. Pathol. 2011, 24, 1462-1469. [CrossRef]

63. Sethmann, I.; Wendt-Nordahl, G.; Knoll, T.; Enzmann, F.; Simon, L.; Kleebe, H.J. Microstructures of Randall's plaques and their interfaces with calcium oxalate monohydrate kidney stones reflect underlying mineral precipitation mechanisms. Urolithiasis 2017, 45, 235-248. [CrossRef]

64. Wiener, S.V.; Chen, L.; Shimotake, A.R.; Kang, M.; Stoller, M.L.; Ho, S.P. Novel insights into renal mineralization and stone formation through advanced imaging modalities. Connect. Tissue Res. 2018, 59, 102-110. [CrossRef]

65. Chmielewska, M.; Symonowicz, K.; Pula, B.; Owczarek, T.; Podhorska-Okolow, M.; Ugorski, M.; Dziegiel, P. Expression of metallothioneins I and II in kidney of doxorubicin-treated rats. Exp. Toxicol. Pathol. 2015, 67, 297-303. [CrossRef]

66. Schanz, M.; Schaaf, L.; Dippon, J.; Biegger, D.; Fritz, P.; Alscher, M.D.; Kimmel, M. Renal effects of metallothionein induction by zinc in vitro and in vivo. BMC Nephrol. 2017, 18, 91. [CrossRef]

67. Goyer, R.A. Mechanisms of lead and cadmium nephrotoxicity. Toxicol. Lett. 1989, 46, 153-162. [CrossRef]

68. Rango, T.; Jeuland, M.; Manthrithilake, H.; McCornick, P. Nephrotoxic contaminants in drinking water and urine, and chronic kidney disease in rural Sri Lanka. Sci. Total Environ. 2015, 518, 574-585. [CrossRef] [PubMed]

69. Dharmawardana, M.W.; Amarasiri, S.L.; Dharmawardene, N.; Panabokke, C.R. Chronic kidney disease of unknown aetiology and ground-water ionicity: Study based on Sri Lanka. Environ. Geochem. Health 2014, 37, 221-231. [CrossRef] [PubMed]

70. Wimalawansa, S.A.; Wimalawansa, S.J. Clean water, healthy environment, and preservation of watersheds: Correct, enforceable policies are essential. Jacobs J. Hydrol. 2015, 1, 3-15. [CrossRef]

71. Edirisinghe, E.; Manthrithilake, H.; Pitawala, H.; Dharmagunawardhane, H.A.; Wijayawardane, R.L. Geochemical and isotopic evidences from groundwater and surface water for understanding of natural contamination in chronic kidney disease of unknown etiology (CKDu) endemic zones in Sri Lanka. Isot. Environ. Health Stud. 2018, 54, 244-261. [CrossRef]

72. Wanigasuriya, K.P.; Peiris-John, R.J.; Wickremasinghe, R. Chronic kidney disease of unknown aetiology in Sri Lanka: Is cadmium a likely cause? BMC Nephrol. 2011, 12, 32. [CrossRef]

73. Jayathilaka, N.M.P.; Mendis, S.; Mehta, F.R.; Dissanayake, L.J.; Janakan, N. Investigation and Evaluaiton of Chronic Kidney Disease of Uncertain Aetiology in Sri Lanka (Final Report); WHO: Colombo, Sri Lanka, 2013.

74. WHO. International Expert Consultation on Chronic Kidney Disease of Unknown Etiology (CKDu) in Sri Lanka; WHO Country Office: Colombo, Sri Lanka, 2016; ISBN 978-955-0261-15-4.

75. Senevirathna, L.; Abeysekera, T.; Nanayakkara, S.; Chandrajith, R.; Ratnatunga, N.; Harada, K.H.; Hitomi, T.; Komiya, T.; Muso, E.; Koizumi, A. Risk factors associated with disease progression and mortality in chronic kidney disease of uncertain etiology: A cohort study in Medawachchiya, Sri Lanka. Environ. Health Prev. Med. 2012, 17, 191-198. [CrossRef]

76. Nanayakkara, S.; Senevirathna, S.; Harada, K.H.; Chandrajith, R.; Hitomi, T.; Abeysekera, T.; Muso, E.; Watanabe, T.; Koizumi, A. Systematic evaluation of exposure to trace elements and minerals in patients with chronic kidney disease of uncertain etiology (CKDu) in Sri Lanka. J. Trace Elem. Med. Biol. 2019, 54, $206-213$. [CrossRef]

77. WHO. Guidelines for Drinking-Water Quality, Incorporating the 1st Addendum, in Water Sanitation Hygiene, 4th ed.; World Health Organization: Geneva, Switzerland, 2017; ISBN 978-92-4-154995-0. Available online: https://www.who.int/water_sanitation_health/publications/drinking-water-quality-guidelines-4including-1st-addendum/en/ (accessed on 20 November 2019). 
78. WHO. Developing Drinking-Water Quality Regulations and Standards; WHO: Geneva, Switzerland, 2018; Available online: https://www.who.int/water_sanitation_health/publications/developing-dwq-regulations/ en/ (accessed on 20 November 2019).

79. Panabokke, C.R. Nature of occurrence and sustainable use of groundwater resources for agriculture in the North Central, North Western and North Eastern regions in Sri Lanka. Trop. Agric. Res. Ext. 2003, 6, 8-13.

80. Wimalawansa, S.A.; Wimalawansa, S.J. Impact of changing agricultural practices on human health: Chronic kidney disease of multi-factorial origin in Sri Lanka. Wudpecker J. Agric. Res. 2014, 3, 110-124.

81. Amerasinghe, F.P.; Munasingha, N.B. A predevelopment mosquito survey in the Mahaweli Development Project area, Sri Lanka: Immatures. J. Med. Entomol. 1988, 25, 286-294. [CrossRef] [PubMed]

82. Weeraratne, S.; Wimalawansa, S.J. A Major irrigation project (Accelerated Mahaweli Programme) and the chronic kidney disease of multifactorial origin in Sri Lanka. Int. J. Environ. Agric. Res. 2015, 1, 16-27.

83. Wimalawansa, S.; Ileperuma, O.; Weeraratne, S. Attempts to Change the Globally Accepted Term, CKDu, to KDUCAL, NUCAL, or CINAC Are Inappropriate. Am. J. Kidney Dis. 2018, 71, 914. [CrossRef] [PubMed]

84. Chandrajith, R.; Dissanayake, C.B.; Tobschall, H.J. The abundances of rarer trace elements in paddy (rice) soils of Sri Lanka. Chemosphere 2005, 58, 1415-1420. [CrossRef]

85. Dharmagunawardhane, H.A.; Dissanayake, C.B. Fluoride problemsc in Sri Lanka. Environ. Manag. Health 1993, 4, 9-16. [CrossRef]

86. Dissanayake, C. Water quality in the dry Zone of Sri Lanka-Some interesting health aspects. J. Natl. Sci. Found. Sri Lanka 2005, 33, 161-168. [CrossRef]

87. Dissanayake, C.B.; Chandrajith, R. Medical geology in tropical countries with special reference to Sri Lanka. Environ. Geochem. Health 2007, 29, 155-162. [CrossRef]

88. Multiple-References. Estimated “Threshold" Doses for Skeletal Fluorosis. 2012. [cited on 7 July 2019]. Available online: http://fluoridealert.org/studies/skeletal_fluorosis04/ (accessed on 23 December 2019).

89. Manji, F.; Kapila, S. Fluorides and fluorosis in Kenya. Part II: The occurrence of dental and skeletal fluorosis. Odontostomatol. Trop. 1986, 9, 71-74.

90. Arumugam, E.; Harinathbabu, M.; Thillaigovindan, R.; Prabhu, G. Marble Bone Disease: A Rare Bone Disorder. Cureus 2015, 7, e339. [CrossRef]

91. Askmyr, M.K.; Fasth, A.; Richter, J. Towards a better understanding and new therapeutics of osteopetrosis. Br. J. Haematol. 2008, 140, 597-609. [CrossRef] [PubMed]

92. Kuno, M. Cooperative electrogenic proton transport pathways in the plasma membrane of the proton-secreting osteoclast. Pflügers Arch. 2018, 470, 851-866. [CrossRef] [PubMed]

93. Laway, B.A.; Mubarik, I. Renal Tubular Acidosis, Osteopetrosis, and Cerebral Calcification: A Rare Syndrome Caused by Carbonic Anhydrase II Deficiency. Indian J. Nephrol. 2017, 27, 330-331. [CrossRef] [PubMed]

94. Stefanovic, V.; Cukuranovic, R.; Miljkovic, S.; Marinkovic, D.; Toncheva, D. Fifty years of Balkan endemic nephropathy: Challenges of study using epidemiological method. Ren. Fail. 2009, 31, 409-418. [CrossRef]

95. Meharg, A.A.; Rahman, M.M. Arsenic contamination of Bangladesh paddy field soils: Implications for rice contribution to arsenic consumption. Environ. Sci. Technol. 2003, 37, 229-234. [CrossRef]

96. Rahman, M.M.; Chowdhury, U.K.; Mukherjee, S.C.; Mondal, B.K.; Paul, K.; Lodh, D.; Biswas, B.K.; Chanda, C.R.; Basu, G.K.; Saha, K.C.; et al. Chronic arsenic toxicity in Bangladesh and West Bengal, India-a review and commentary. J. Toxicol. Clin. Toxicol. 2001, 39, 683-700. [CrossRef]

97. Saint-Jacques, N.; Brown, P.; Nauta, L.; Boxall, J.; Parker, L.; Dummer, T.J.B. Estimating the risk of bladder and kidney cancer from exposure to low-levels of arsenic in drinking water, Nova Scotia, Canada. Environ. Int. 2018, 110, 95-104. [CrossRef]

98. Tao, H.; Xia, S.M.; Chan, Z.Y.; Song, G.; Yanagihara, R. Morphology and morphogenesis of viruses of hemorrhagic fever with renal syndrome. II. Inclusion bodies-Ultrastructural markers of hantavirus-infected cells. Intervirology 1987, 27, 45-52. [CrossRef]

99. Borges, F.T.; Melo, S.A.; Özdemir, B.C.; Kato, N.; Revuelta, I.; Miller, C.A.; Gattone, V.H.; LeBleu, V.S.; Kalluri, R. TGF-beta1-containing exosomes from injured epithelial cells activate fibroblasts to initiate tissue regenerative responses and fibrosis. J. Am. Soc. Nephrol. 2013, 24, 385-392. [CrossRef]

100. Okada, H. A new look at tubulointerstitial communication with exosomes. J. Am. Soc. Nephrol. 2013, 24, 330-332. [CrossRef] 
101. Zhou, H.; Cheruvanky, A.; Hu, X.; Matsumoto, T.; Hiramatsu, N.; Cho, M.E.; Berger, A.; Leelahavanichkul, A.; Doi, K.; Chawla, L.S.; et al. Urinary exosomal transcription factors, a new class of biomarkers for renal disease. Kidney Int. 2008, 74, 613-621. [CrossRef] [PubMed]

102. Zhou, H.; Pisitkun, T.; Aponte, A.; Yuen, P.S.; Hoffert, J.D.; Yasuda, H.; Hu, X.; Chawla, L.; Shen, R.F.; Knepper, M.A.; et al. Exosomal Fetuin-A identified by proteomics: A novel urinary biomarker for detecting acute kidney injury. Kidney Int. 2006, 70, 1847-1857. [CrossRef] [PubMed]

103. Ranghino, A.; Dimuccio, V.; Papadimitriou, E.; Bussolati, B. Extracellular vesicles in the urine: Markers and mediators of tissue damage and regeneration. Clin. Kidney J. 2015, 8, 23-30. [CrossRef]

104. Elin, R.J. Assessment of magnesium status. Clin. Chem. 1987, 33, 1965-1970. [PubMed]

105. Blaine, J.; Chonchol, M.; Levi, M. Renal control of calcium, phosphate, and magnesium homeostasis. Clin. J. Am. Soc. Nephrol. 2015, 10, 1257-1272. [CrossRef]

106. Wasana, H.M.; Perera, G.D.; De Gunawardena, P.S.; Bandara, J. The impact of aluminum, fluoride, and aluminum-fluoride complexes in drinking water on chronic kidney disease. Environ. Sci. Pollut. Res. Int. 2015, 22, 11001-11009. [CrossRef]

107. Wasana, H.M.; Perera, G.D.; Gunawardena, P.S.; Fernando, P.S.; Bandara, J. WHO water quality standards Vs Synergic effect(s) of fluoride, heavy metals and hardness in drinking water on kidney tissues. Sci. Rep. 2017, 7, 42516. [CrossRef]

108. Wasana, H.M.; Aluthpatabendi, D.; Kularatne, W.M.; Wijekoon, P.; Weerasooriya, R.; Bandara, J. Drinking water quality and chronic kidney disease of unknown etiology (CKDu): Synergic effects of fluoride, cadmium and hardness of water. Environ. Geochem. Health 2016, 38, 157-168. [CrossRef]

109. Gbadebo, A.M. Groundwater fluoride and dental fluorosis in southwestern Nigeria. Environ. Geochem. Health 2012, 34, 597-604. [CrossRef]

110. Czajka-Jakubowska, A.E.; Liu, J.; Chang, S.R.; Clarkson, B.H. The effect of the surface characteristics of various substrates on fluorapatite crystal growth, alignment, and spatial orientation. Med. Sci. Monit. 2009, 15, MT84-MT88.

111. Skwarek, E.; Bolbukh, Y.; Janush, W. Hydroxyapatite composites with multiwalled carbon nanotubes. Adsorpt. Sci. Technol. 2017, 35, 534-544. [CrossRef]

112. Arnich, N.; Lanhers, M.C.; Laurensot, F.; Podor, R.; Montiel, A.; Burnel, D. In vitro and in vivo studies of lead immobilization by synthetic hydroxyapatite. Environ. Pollut. 2003, 124, 139-149. [CrossRef]

113. Zhu, Y.; Huang, B.; Zhu, Z.; Liu, H.; Huang, Y.; Zhao, X.; Liang, M. Characterization, dissolution and solubility of the hydroxypyromorphite-hydroxyapatite solid solution $\left[\left(\mathrm{Pb}_{\mathrm{x}} \mathrm{Ca}_{1-\mathrm{x}}\right)_{5}\left(\mathrm{PO}_{4}\right)_{3} \mathrm{OH}\right]$ at 25 degrees $\mathrm{C}$ and pH 2-9. Geochem. Trans. 2016, 17, 2. [CrossRef] [PubMed]

114. McDowell, H.; Gregory, T.M.; Brown, W.E. Solubility of $\mathrm{Ca}_{5}\left(\mathrm{PO}_{4}\right)_{3} \mathrm{OH}$ in the System $\mathrm{Ca}(\mathrm{OH})_{2}-\mathrm{H}_{3} \mathrm{PO}_{4}-\mathrm{H}_{2} \mathrm{O}$, at 5, 15, 25, and $37^{\circ}$ C. J. Res. Natl. Bur. Stand. Phys. Chem. 1877, 81, 273-281.

115. Buzea, C.; Ivan, I.; Pacheco Blandino, I.I.P.; Kevin Robbie, K. Nanomaterials and nanoparticles: Sources and toxicity. Biointerphases 2007, 2, MR17-MR172. [CrossRef] [PubMed]

116. Aoshima, K. Itai-itai disease: Lessons from the investigations of environmental epidemiology conducted in the 1970's, with special reference to the studies of the Toyama Institute of Health. Nihon Eiseigaku Zasshi. Jpn. J. Hyg. 2017, 72, 149-158. [CrossRef] [PubMed]

117. Saint-Jacques, N.; Parker, L.; Brown, P.; Dummer, T.J. Arsenic in drinking water and urinary tract cancers: A systematic review of 30 years of epidemiological evidence. Environ. Health 2014, 13, 44. [CrossRef]

118. Wickramarathna, S.; Balasooriya, S.; Diyabalanage, S.; Chandrajith, R. Tracing environmental aetiological factors of chronic kidney diseases in the dry zone of Sri Lanka-A hydrogeochemical and isotope approach. J. Trace Elem. Med. Biol. 2017, 44, 298-306. [CrossRef]

119. Reddy, D.V.; Nagabhushanam, P.; Sukhija, B.S.; Reddy, A.G.S.; Smedley, P.L. Fluoride dynamics in the granitic aquifer of the Wailapally watershed, Nalgonda District India. Chem. Geol. 2010, 269, 278-289. [CrossRef]

120. Smedley, P.L.; Nicolli, H.B.; Macdonald, D.M.J.; Barros, A.J.; Tullio, J.O. Hydrogeochemistry of arsenic and other inorganic constituents in groundwaters from La Pampa, Argentina. Appl. Geochem. 2002, 17, $259-284$. [CrossRef]

121. Battaleb-Looie, S.; Moore, F.; Jacks, G.; Ketabdari, M.R. Geological sources of fluoride and acceptable intake of fluoride in an endemic fluorosis area, southern Iran. Environ. Geochem. Health 2012, 34, 641-650. [CrossRef] [PubMed] 
122. Sayanthooran, S.; Gunerathne, L.; Abeysekera, T.D.J.; Magana-Arachchi, D.N. Transcriptome analysis supports viral infection and fluoride toxicity as contributors to chronic kidney disease of unknown etiology (CKDu) in Sri Lanka. Int. Urol. Nephrol. 2018, 50, 1667-1677. [CrossRef] [PubMed]

123. Gamage, C.D.; Yoshimatsu, K.; Sarathkumara, Y.D.; Kulendiran, T.; Nanayakkara, N.; Arikawa, J. Serological evidence of hantavirus infection in Girandurukotte, an area endemic for chronic kidney disease of unknown aetiology (CKDu) in Sri Lanka. Int. J. Infect. Dis. 2017, 57, 77-78. [CrossRef] [PubMed]

124. Nanayakkara, S.; Senevirathna, S.T.; Abeysekera, T.; Chandrajith, R.; Ratnatunga, N.; Gunarathne, E.D.; Yan, J.; Hitomi, T.; Muso, E.; Komiya, T.; et al. An integrative study of the genetic, social and environmental determinants of chronic kidney disease characterized by tubulointerstitial damages in the North Central Region of Sri Lanka. J. Occup. Health 2014, 56, 28-38. [CrossRef] [PubMed]

125. Ordak, M.; Maj-Zurawska, M.; Matsumoto, H.; Bujalska-Zadrozny, M.; Kieres-Salomonski, I.; Nasierowski, T.; Muszynska, E.; Wojnar, M. Ionized magnesium in plasma and erythrocytes for the assessment of low magnesium status in alcohol dependent patients. Drug Alcohol. Depend. 2017, 178, 271-276. [CrossRef] [PubMed]

126. Eberhard, J.; Macdonald, A.; Cundy, T. Severe proton pump inhibitor-induced hypomagnesaemia in a mother and daughter. Intern. Med. J. 2017, 47,341-342. [CrossRef]

127. Hess, M.W.; Hoenderop, J.G.; Bindels, R.J.; Drenth, J.P. Systematic review: Hypomagnesaemia induced by proton pump inhibition. Aliment. Pharmacol. Ther. 2012, 36, 405-413. [CrossRef]

128. Van Angelen, A.A.; Glaudemans, B.; van der Kemp, A.W.; Hoenderop, J.G.; Bindels, R.J. Cisplatin-induced injury of the renal distal convoluted tubule is associated with hypomagnesaemia in mice. Nephrol. Dial. Transpl. 2013, 28, 879-889. [CrossRef]

129. Lameris, A.L.; Monnens, L.A.; Bindels, R.J.; Hoenderop, J.G. Drug-induced alterations in Mg2+ homoeostasis. Clin. Sci. (Lond.) 2012, 123, 1-14. [CrossRef]

130. Van de Wal-Visscher, E.R.; Kooman, J.P.; van der Sande, F.M. Magnesium in Chronic Kidney Disease: Should We Care? Blood Purif. 2018, 45, 173-178. [CrossRef]

(C) 2019 by the authors. Licensee MDPI, Basel, Switzerland. This article is an open access article distributed under the terms and conditions of the Creative Commons Attribution (CC BY) license (http://creativecommons.org/licenses/by/4.0/). 